\title{
Transport of pollution to a remote coastal site during gap flow from California's interior: impacts on aerosol composition, clouds, and radiative balance
}

\author{
Andrew C. Martin ${ }^{1, *}$, Gavin C. Cornwell ${ }^{2, *}$, Samuel A. Atwood ${ }^{3}$, Kathryn A. Moore ${ }^{2, a}$, Nicholas E. Rothfuss ${ }^{4}$, \\ Hans Taylor ${ }^{4}$, Paul J. DeMott ${ }^{3}$, Sonia M. Kreidenweis ${ }^{3}$, Markus D. Petters ${ }^{4}$, and Kimberly A. Prather ${ }^{1,2}$ \\ ${ }^{1}$ Climate Atmospheric Science and Physical Oceanography, Scripps Institution of Oceanography, La Jolla, CA, USA \\ ${ }^{2}$ Department of Chemistry and Biochemistry, University of California San Diego, La Jolla, CA, USA \\ ${ }^{3}$ Department of Atmospheric Science, Colorado State University, Fort Collins, CO, USA \\ ${ }^{4}$ Department of Marine Earth and Atmospheric Sciences, North Carolina State University, Raleigh, NC, USA \\ ${ }^{a}$ now at: School of Chemistry, University of St. Andrews, St. Andrews, UK \\ ${ }^{*}$ These authors contributed equally to this work. \\ Correspondence to: Kimberly A. Prather (kprather@ucsd.edu)
}

Received: 27 May 2016 - Published in Atmos. Chem. Phys. Discuss.: 1 June 2016

Revised: 16 September 2016 - Accepted: 30 September 2016 - Published: 31 January 2017

\begin{abstract}
During the CalWater 2015 field campaign, ground-level observations of aerosol size, concentration, chemical composition, and cloud activity were made at Bodega Bay, CA, on the remote California coast. A strong anthropogenic influence on air quality, aerosol physicochemical properties, and cloud activity was observed at Bodega Bay during periods with special weather conditions, known as Petaluma Gap flow, in which air from California's interior is transported to the coast. This study applies a diverse set of chemical, cloud microphysical, and meteorological measurements to the Petaluma Gap flow phenomenon for the first time. It is demonstrated that the sudden and often dramatic change in aerosol properties is strongly related to regional meteorology and anthropogenically influenced chemical processes in California's Central Valley. In addition, it is demonstrated that the change in air mass properties from those typical of a remote marine environment to properties of a continental regime has the potential to impact atmospheric radiative balance and cloud formation in ways that must be accounted for in regional climate simulations.
\end{abstract}

\section{Introduction}

The remote northern California coast experiences a Mediterranean climate (Aschmann, 1973; Lentz and Chapman, 1989) and warm, dry summers. The vast majority of yearly precipitation occurs during winter (Regonda et al., 2005), when the North Pacific extratropical storm track extends southward and brings periodic pressure falls and rain to the region (Gyakum et al., 1989). Also during the winter months, conditions known as channeled gap flow can transport air masses from much further inland to the remote coast. These episodic periods result when very low near-surface buoyancy and an onshore-directed gap-parallel pressure gradient co-occur in one of several prominent gaps in the coastal mountain ranges (Overland and Walter Jr., 1981; Neiman et al., 2006; Loescher et al., 2006; Colle et al., 2006). One such prominent gap is located near the town of Petaluma in Sonoma County, CA, and can act to channel air from the north San Francisco Bay Area (SFBA), the Sacramento River Delta, and California's Central Valley (CV) to coastal northern California (see schematic in Fig. 1; Neiman et al., 2006 - hereafter N06). N06 described the regional weather patterns and lower-tropospheric dynamic meteorology associated with Petaluma Gap flow (PGF) using 62 cases observed during the multi-winter deployment of a $915 \mathrm{MHz}$ wind profiling radar to Bodega Bay, CA. N06 described PGF 

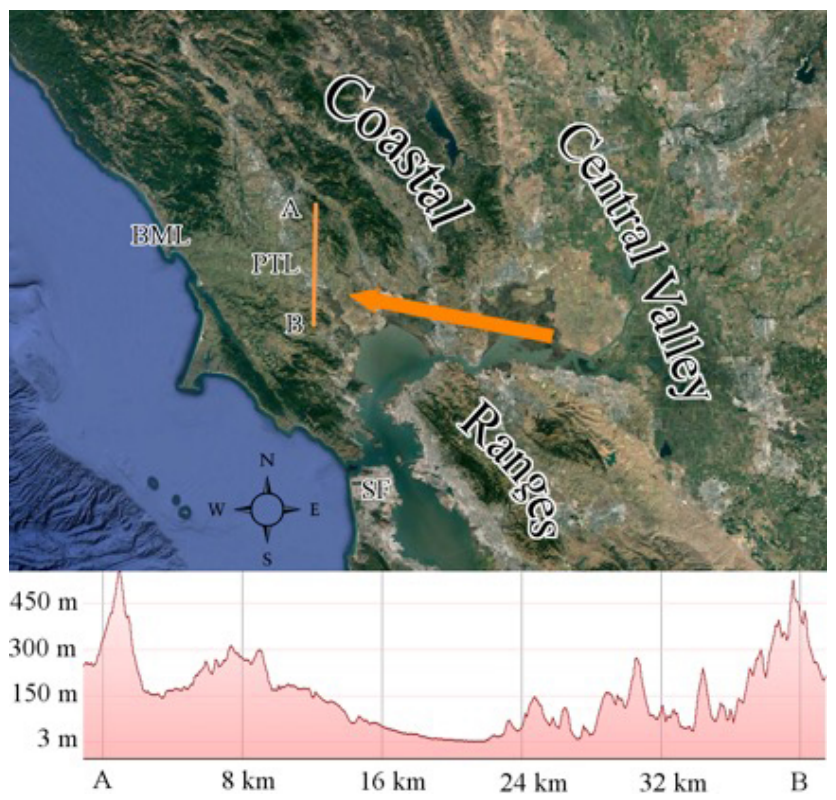

Figure 1. Regional map displaying the location of BML, the town of Petaluma, CA (PTL); San Francisco, CA (SF); the Central Valley; and the Coastal Ranges. The orange arrow depicts the direction of typical flow during PGF conditions. Line A-B traces a path across the Petaluma Gap. The inset at bottom displays the cross-gap terrain profile along line A-B.

as a near-surface shallow $(\sim 500 \mathrm{~m})$ stably stratified quasiBernoulli flow which can lead to increased static stability, increased density, lower relative humidity, and increased anthropogenic pollutants near Bodega Bay and offshore.

Evidence presented in N06 for the proliferation of anthropogenic pollutants at the coast during PGF included horizontal coast-normal transects and low-troposphere vertical profiles of carbon monoxide (CO) mixing ratio from a trace gas analyzer on board just one research flight of the National Oceanographic and Atmospheric Administration (NOAA) P3 aircraft. During the coast-normal transect $\mathrm{CO}$ mixing ratio doubled from 120 to $240 \mathrm{ppbv}$ across a $20 \mathrm{~km}$ wide gradient that was located approximately $75 \mathrm{~km}$ offshore of Bodega Bay and Point Reyes, CA. It was inferred that, when the nearsurface air mass during PGF episodes traveled from the polluted Central Valley region before arriving at the coast, the air mass would acquire properties commensurate with combustion, transportation, agriculture, and manufacturing (e.g., the observation of elevated $\mathrm{CO}$ concentration).

When transport occurs, PGF should cause large measurable impacts on the coastal environment via an abrupt but significant change in trace gas and aerosol chemistry. Expected impacts include the following:

- An increase in absorption of solar shortwave radiation by black carbon (BC) aerosol, which has much greater emission sources on the continental side of the Petaluma Gap. An increase in black carbon mass may also be as- sociated with more freshly emitted soot. Together, these factors may lead to a relative decrease in both externally mixed and internally mixed organic: elemental carbon (OC: EC) ratios. (e.g., Chung et al., 2012; Cahill et al., 2012).

- A brightening in nearshore marine stratocumulus clouds through the cloud albedo indirect effect (Twomey, 1977; Solomon, 2007), since the inferred PGF air mass contains more numerous pollution aerosol particles, a portion of which will serve as cloud condensation nuclei $(\mathrm{CCN})$.

- Increased deposition of nitrogen-containing particulate matter to the local ecosystem, which may lead to increased eutrophication along the coastal shelf (Paerl, 1995, 1997), because particles transported during PGF may have formed or have been aged in a nitrous-oxideand ammonia-enriched environment (Seinfeld and Pandis, 2012).

As part of the CalWater-2 experiment (Leung et al., 2014; Ralph et al., 2015), measurements of trace gas concentrations, aerosol physicochemical properties, and lowertropospheric meteorology were taken at the University of California, Davis Bodega Marine Laboratory during January, February, and March 2015. Using this dataset, described in Sect. 2, we report the abrupt changes in trace gases and particulate matter observed during five PGF events and establish composite aerosol size distributions, aerosol chemical sources, trace gas concentrations, and cloud condensation nuclei activation curves. We also identify particle aging through the accumulation of ammonium and nitrate during PGF using detailed single-particle mass spectrometry measurements. The analysis methods presented in Sect. 3, and their results, presented in Sect. 4, verify the above hypotheses and present a nuanced picture of the secondary heterogeneous chemistry active in aerosol particles that travel to the coast in the PGF air mass. Fine details of particle aging are location specific, but conclusions drawn from the increase in aerosol number, changes in aerosol source, brightening of marine clouds, and impact on aerosol absorption are generally applicable to many other coastal regions that periodically experience channeled offshore flow through a mountain gap.

\section{Data sources}

\subsection{Bodega Marine Laboratory}

Measurements and samples were collected from 14 January to 9 March 2015 at Bodega Marine Laboratory (BML; $38^{\circ} 19^{\prime} \mathrm{N}, 123^{\circ} 4^{\prime} \mathrm{W}$ ) in Bodega Bay, California. Measurements were collected continuously unless otherwise noted. BML is located south-southwest of the northern California coastal mountain ranges and north of Point Reyes National 
Seashore (Fig. 1). More detailed information regarding instrumentation deployed to BML follows below.

The sampling site at BML included two instrumented trailers located $\sim 100 \mathrm{~m}$ east-northeast of the seashore and $\sim 30 \mathrm{~m}$ north of the northernmost BML permanent building. The beta attenuation monitor (BAM), for measuring particulate matter mass for particles smaller than $2.5 \mu \mathrm{m}\left(\mathrm{PM}_{2.5}\right)$, and Interagency Monitoring of Protected Visual Environments (IMPROVE; Eldred et al., 1997) filters for collecting $\mathrm{PM}_{2.5}$ and particles smaller than $10 \mu \mathrm{m}\left(\mathrm{PM}_{10}\right)$ were placed at an ancillary site $\sim 15 \mathrm{~m}$ southwest of the trailers. The IMPROVE samples are not used in the analysis that follows. Aerosol composition and ice-nucleating particle concentrations were measured in the trailer owned by the California Air Resources Board (CARB) and operated by the University of California, San Diego (UCSD). Aerosol sizing, gas-phase tracer concentrations, black carbon mass, and cloud condensation nuclei concentrations were measured in the trailer owned by the National Park Service (NPS) and operated by Colorado State University (CSU). Ambient aerosol particles were collected nearby using filters for subsequent laboratory measurement of drop freezing temperature. A more extensive description of these instruments and the data processing, quality control, and archiving is given by Petters et al. (2017). A meteorology station operated by the National Oceanic and Atmospheric Administration's Earth System Research Laboratory (NOAA/ESRL) was located $\sim 100 \mathrm{~m}$ north of the two trailers. The NOAA/ESRL $449 \mathrm{MHz}$ wind profiling radar, radio acoustic sounding system (RASS), and $10 \mathrm{~m}$ surface meteorology tower were operated during the two study periods and are used for the analysis presented in later sections. Descriptions of these instruments and the NOAA/ESRL Bodega Bay meteorology station (BBY) can be found in White et al. (2013).

\subsection{Aerosol composition}

Size-resolved aerosol composition at Bodega Bay was measured with an aerosol time-of-flight mass spectrometer (ATOFMS) and an ultrafine aerosol time-of-flight mass spectrometer (UF-ATOFMS). The UF-ATOFMS used a diluting stage with an approximate dilution of $5 \times$ to increase aerosol ionization efficiency during periodic high particle concentrations. The use of these instruments in tandem allows the direct measurement of single-particle composition for particles in the aerodynamic diameter range $0.15-3.0 \mu \mathrm{m}$. The design and operating principles of these instruments have been described elsewhere (Gard et al., 1997; Su et al., 2004); thus we provide only a short overview here. Particles were dried prior to introduction to the instrument with silica-diffusion dryers in order to improve the ionization efficiency and thus improve the acquired spectra quality. Particles enter the vacuum system through either a converging nozzle or an aerodynamic lens, wherein they are accelerated to their terminal velocities. After reaching this terminal velocity, they enter the sizing region, where they travel through two continuous wave laser beams (diode-pumped, Nd: YAG at $532 \mathrm{~nm}$ ) separated by a vertical distance of $6 \mathrm{~cm}$ and oriented orthogonal to each other. Because the distance is known, particle velocity can be determined by measuring the time difference between the two scattering signals. These velocities can be converted to vacuum aerodynamic diameter $\left(D_{\mathrm{va}}\right)$ through a calibration curve generated with polystyrene latex spheres (PSLs). The velocity is also used to calculate the time when a particle will arrive in the ion source region. Upon arrival in the source region, a $266 \mathrm{~nm} \mathrm{Nd}$ : YAG laser is triggered to fire upon the particle, desorb it, and generate positive and negative ions whose mass spectrum are measured with a dualpolarity time-of-flight mass spectrometer.

\subsection{Size distributions}

Aerosol size distributions at BML were measured using a scanning mobility particle sizer (SMPS, TSI Inc. Model 3936) and an aerodynamic particle sizer (APS, TSI Inc. Model 3321). The SMPS was operated with a pump flow of $0.3 \mathrm{~L} \mathrm{~min}^{-1}$ and a sheath flow of $3.0 \mathrm{~L} \mathrm{~min}^{-1}$ so that the dynamic size range varied from 13.6 to $736.5 \mathrm{~nm}$. The APS operated with a sample flow rate of $1.0 \mathrm{~L} \mathrm{~min}^{-1}$ and a sheath flow of $4.0 \mathrm{~L} \mathrm{~min}^{-1}$ and measured particle sizes from 0.6 to $20 \mu \mathrm{m}$. The APS was externally calibrated using PSLs. Particles were not dried prior to sizing, but the relative humidity (RH) of the sample line was monitored with a RH sensor (Vaisala, HMP110). The RH in the sample line varied from 7.5 to $54.7 \%$ during measurement periods with a mean value of $35.5 \%$. Nearly $97 \%$ of the sampling periods occurred while sample line RH was below $47 \%$ (0.4\% of local (LOCAL), $4.7 \%$ of control (CTL), and $0 \%$ of PGF; refer to Sect. 3.1): the efflorescence humidity of sodium chloride particles (Gupta et al., 2015). Because the RH was below the efflorescence point of sodium chloride (chosen as a proxy for sea spray) for $>95 \%$ of the sampling periods, the humidity likely had little bearing on the composite size distributions used in this analysis. Assuming spherical particles, the measured mobility diameter $\left(D_{\mathrm{m}}\right)$ is equivalent to physical diameter $\left(D_{\mathrm{p}}\right)$. APS measurements were adjusted from aerodynamic diameter $\left(D_{\mathrm{a}}\right)$ to $D_{\mathrm{p}}$ assuming spherical particles and an effective density of $1.8 \mathrm{~g} \mathrm{~cm}^{-3}$. Both APS and SMPS size distributions were combined to 10 min mean distributions from their operational 1 and 5 min scan frequency.

\subsection{Aerosol and BC mass concentration}

$\mathrm{PM}_{2.5}$ mass was determined using a BAM (Met One Instruments Inc., Model BAM 1020). The mass was recorded hourly. BC mass concentration and attenuation were determined with a seven-channel aethalometer (Magee Scientific Corp., Model AE16-ER-P3-F0), operating in AE-30 mode. 


\subsection{Cloud activation properties}

Size-resolved (also referred to as "diameter scan") cloud condensation nuclei concentrations were measured using a streamwise cloud condensation nuclei counter (Droplet Measurement Technologies Inc., CCN-100) coupled with an SMPS. The SMPS (TSI 3080 long column) was operated at a sheath-to-sample flow rate of 5 to $1.3 \mathrm{~L} \mathrm{~min}^{-1}$. Raw counts were recorded in Labview and inverted as described previously (Nguyen et al., 2014; Petters et al., 2009). The inversions account for temperature and pressure changes inside the DMA, contribution of multiply charged particles, and losses through the inlet system. The CCN was operated at a sample flow rate of $0.3 \mathrm{~L} \mathrm{~min}^{-1}$ and sheath-to-sample flow ratio of $10: 1$. Supersaturation is calibrated using atomized, dried ammonium sulfate aerosol (Christensen and Petters, 2012). The control software cycles through an automated 12-point sequence varying supersaturation between 0.06 and $0.67 \%$. Activation diameters are obtained for normalized activation curves (Petters et al., 2009), and the apparent hygroscopicity parameter at standard state, $\kappa$, is calculated from the supersaturation and activation diameter (Christensen and Petters, 2012; Petters and Kreidenweis, 2007).

\subsection{Gas-phase measurements}

Concentrations of gas-phase pollutants were determined using a suite of gas-phase instruments, collocated with the aethalometer, $\mathrm{CCN}$ counter, and the sizing instruments. A $\mathrm{NO}-\mathrm{NO}_{2}-\mathrm{NO}_{x}$ analyzer (TEI Inc., Model 42C), ozone analyzer (TEI Inc., Model 49C), sulfur dioxide analyzer (TEI Inc. Model 43C), and carbon monoxide monitor (Horiba Inc., APMA-370) were all utilized in this study. Gas-phase measurements were recorded every second and converted to 10 min mean time resolution.

\subsection{Remotely sensed cloud properties}

Level 2 MODIS cloud products (Platnick et al., 2003) are used to estimate the range of marine stratocumulus cloud optical depth offshore from BML during PGF episodes with clear sky above low clouds, and to verify that the clouds in nearshore MODIS scenes are low-level cumulus or stratocumulus clouds.

\section{Methods}

\subsection{Method of compositing by measurement period}

Composite aerosol size distributions, trace gas and aerosol type concentrations, indicators of secondary chemical aging, and CCN activation spectra corresponding to PGF periods and control periods are derived as a primary tool for addressing the hypotheses posed in this study. Herein, we define a control period (CTL) to be any hourly period which does not fit the definition for flow through the Petaluma Gap arriving at BML found in N06 (hereafter mPGF) and does not occur during short-lived episodes of concentrated local anthropogenic pollution. In this study, mPGF periods that also meet a minimum threshold for concentrated non-local anthropogenic pollution will be called PGF. Observed causes of local anthropogenic pollution included nearby brush fires, vehicle activity at BML, and "sea breeze resampling". During the third of those, high concentrations of anthropogenic pollution either from a local source or from further inland that was previously transported offshore returned to the measurement site via the afternoon sea breeze. Since the polluted air mass may have up to $18 \mathrm{~h}$ of modification by the nearby BML marine environment just before sea breeze resampling episodes, these were classified as local anthropogenic pollution and were removed from the PGF and CTL composites.

We followed the methodology of N06 in identifying Petaluma Gap flow using the BBY $449 \mathrm{MHz}$ vertically profiling radar and $10 \mathrm{~m}$ anemometer (see Sect. $4 \mathrm{a}$ in N06). Briefly, this methodology includes identifying continuous periods at least $6 \mathrm{~h}$ in length during which wind speed and direction criteria are met both at the surface $(10 \mathrm{~m}$ anemometer at BML) and in the lowest retrieved layer (approximately 100 to $350 \mathrm{~m}$ m.s.l.) of the BML $449 \mathrm{MHz}$ radar. When the conditions from the N06 methodology were met, we declared the period mPGF. It is important to note that, while $449 \mathrm{MHz}$ wind profiles are collected hourly, all other data from the study are collected more frequently; therefore we classified local conditions in hourly intervals.

To choose local conditions based on an indicator of anthropogenic pollution, we examined CalWater 2015 observations of $\mathrm{CO}, \mathrm{NO}_{x}$, SMPS number concentration integrated from 13.6 to $736.5 \mathrm{~nm}(\mathrm{CN})$, and $\mathrm{PM}_{2.5}$ (collectively, peripherals). During mPGF, the interquartile range of $\mathrm{CO}$ and $\mathrm{NO}_{x}$ was higher than the interquartile range of the same measurements during periods that did not fit mPGF (not shown). In addition, for indicators of fine particulate concentration $\left(\mathrm{CN}, \mathrm{PM}_{2.5}\right)$, the median value during PGF is higher than the upper quartile value during all periods. For all anthropogenic pollutant indicators, the maximum observation and much of the upper quartile range are higher than any observation taken during $\mathrm{mPGF}$, and occurred during local anthropogenic pollution periods. An example is shown in Fig. 2, which contrasts lower tropospheric horizontal wind and virtual potential temperature $\left(\theta_{\mathrm{v}}\right)$, selected peripheral measurements, and EC and SS particle (Table 2) subtypes (see Sect. 3.3 for particle typing, later this section) during a period when mPGF was not observed nor were anthropogenic pollutants high (Fig. 2a), a period when it is suspected local anthropogenic pollutants were sampled (Fig. 2b), and a mPGF period (Fig. 2c). Note that, during the local pollutant episode, $\mathrm{CN}$ and $\mathrm{CO}$ were elevated to the same levels as during the mPGF period for a few hours. The onset of the elevated-pollutant period occurs near the maximum in onshore sea breeze (NNW $200 \mathrm{~m}$ wind near 03:00 UTC on 12 February). Pollutant concentra- 

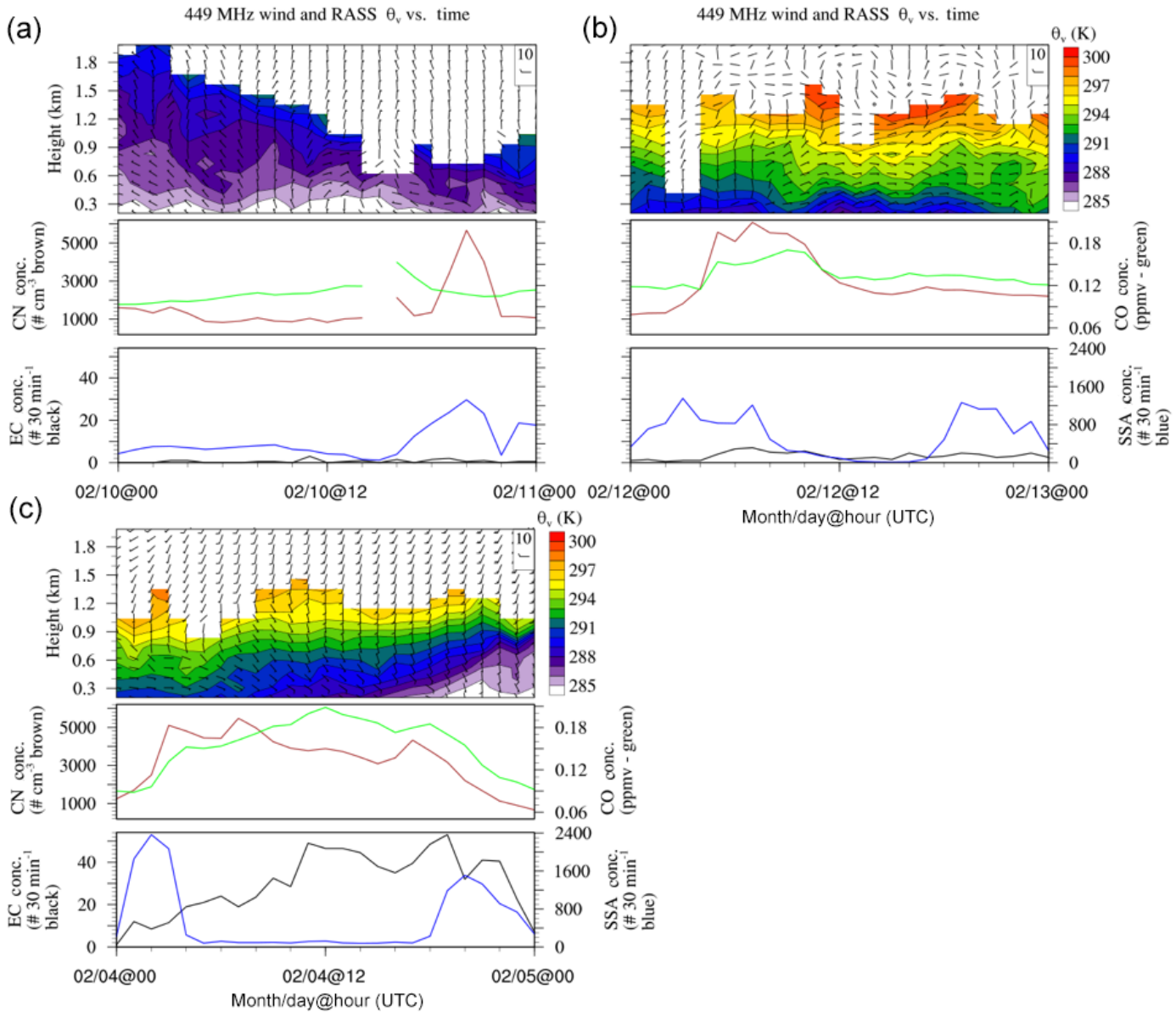

Month/day@hour (UTC)

Figure 2. (a) Horizontal wind barb and $\theta_{\mathrm{v}}$ every $100 \mathrm{~m}$ from 300 to $1900 \mathrm{~m}$ a.g.l. from NOAA/ESRL $449 \mathrm{MHz}$ wind profiling radar and RASS at BBY (top), hourly CO concentration (ppmv - green) and CN (no. $\mathrm{cm}^{-3}$ - brown) (middle), number particles classified as EC or aged EC (black) and SS or aged SS (blue) per 30 min interval from ATOFMS (bottom) during a $24 \mathrm{~h}$ period (10 February 2015) classified as CTL. (b) As in (a) but for a $24 \mathrm{~h}$ period (12 February 2015) classified as LOCAL. (c) As in (a) but for the $24 \mathrm{~h}$ surrounding PGF 4.

Table 1. Decision tree used for filtering measurement periods, and the resulting number of hourly periods (/total) in each category.

\begin{tabular}{|c|c|c|c|}
\hline Decision criteria & \multicolumn{3}{|c|}{3 PGF criteria at BBY (Neiman et al., 2006) } \\
\hline & & Y & $\mathrm{N}$ \\
\hline $\mathrm{CO}$ conc. greater than & Y & PGF (55/1248) & Local (407/1248) \\
\hline$\mu+2 \sigma(138.1 \mathrm{ppbv})$ & $\mathrm{N}$ & $\begin{array}{l}\text { Onset/diffuse } \\
(11 / 1248)\end{array}$ & CTL (775/1248) \\
\hline
\end{tabular}

tions decrease again a few hours after local sunset, when the offshore land breeze become established. The period 03:0011:00 UTC on 12 February 2015 is an example of a sea breeze resampling period.

In order to exclude local or sea breeze resampled anthropogenic pollutants from CTL periods, we imposed an additional requirement based upon $\mathrm{CO}$ concentration - hourly mean CO concentration must be above the CalWater 2015 mean plus two standard deviations (138.1 ppbv). Along with
mPGF, this requirement forms the basis of a decision table (Table 1) that allows the separation of CalWater 2015 measurements into four composites. We choose CO concentration as our additional discriminator because its interquartile range during mPGF is entirely above the interquartile range from all other periods, because its overall variability is the lowest among peripheral measurements, and because elevated near-surface $\mathrm{CO}$ concentration was observed by aircraft during a PGF event reported in N06. Table 1 allows the compositing of observational period by PGF (mPGF and elevated $\mathrm{CO}$ conditions met), CTL (neither mPGF nor elevated CO conditions met), LOCAL (mPGF not met, elevated CO met), and diffuse (mPGF met, elevated CO not met). In this light, Fig. 2a-c can be seen as examples of CTL, LOCAL, and PGF periods, respectively. 
Table 2. Summary of particle types determined by ATOFMS and their characteristic ion markers.

\begin{tabular}{|c|c|}
\hline Particle type & Characteristic peaks \\
\hline Biomass burning (BB) & $\begin{array}{l}\text { Strong }{ }^{39} \mathrm{~K}^{+} \text {and }{ }^{97} \mathrm{HSO}_{4}^{-} \text {, less intense }{ }^{12} \mathrm{C}^{+},{ }^{26} \mathrm{CN}^{-},{ }^{46} \mathrm{NO}_{2}^{-},{ }^{62} \mathrm{NO}_{3}^{-},{ }^{125} \mathrm{H}_{\left(\mathrm{NO}_{3}\right)}{ }_{2}^{-} \\
\text {(Silva et al., 1999) }\end{array}$ \\
\hline Elemental carbon (EC) & Carbon Clusters at $C_{n}^{+}$and $C_{n}^{-}$(Moffett and Prather, 2009; Spencer and Prather, 2006) \\
\hline Elemental carbon-organic carbon (ECOC) & $\begin{array}{l}{ }^{12} \mathrm{C}^{+},{ }^{24} \mathrm{C}_{2}^{+},{ }^{27} \mathrm{C}_{3}^{+},{ }^{36} \mathrm{C}_{3}^{+},{ }^{37} \mathrm{C}_{3} \mathrm{H}^{+},{ }^{43} \mathrm{CH}_{3} \mathrm{CO}^{+} / \mathrm{CHNO}^{+} \text {(Moffet and Prather 2009; } \\
\text { Qin et al., 2012) }\end{array}$ \\
\hline Organic carbon & $\begin{array}{l}{ }^{27} \mathrm{C}_{2} \mathrm{H}_{3}^{+} / \mathrm{CHN}^{+},{ }^{37} \mathrm{C}_{3} \mathrm{H}^{+},{ }^{43} \mathrm{CHNO}^{+} \text {(Silva and Prather, 2000; Spencer and Prather, } \\
\text { 2006; Qin et al., 2012) }\end{array}$ \\
\hline High-mass organic carbon (HMOC) & $\begin{array}{l}{ }^{37} \mathrm{C}_{3} \mathrm{H}^{+},{ }^{43} \mathrm{CHNO}^{+} \text {, differences of } 14-16 \text { past } 150 \mathrm{~m} / z,{ }^{46} \mathrm{NO}_{2}^{-},{ }^{62} \mathrm{NO}_{3},{ }^{97} \mathrm{HSO}_{4}^{-} \\
\text {(Denkenberger et al., 2007; Qin et al., 2006) }\end{array}$ \\
\hline Dust & $\begin{array}{l}\text { Inorganic ions }{ }^{6 / 7} \mathrm{Li}^{+},{ }^{27} \mathrm{Al}^{+},{ }^{39} \mathrm{~K}^{+},{ }^{40} \mathrm{Ca}^{+},{ }^{48 / 64} \mathrm{Ti} / \mathrm{TiO}^{+},{ }^{54 / 56} \mathrm{Fe}^{+},{ }^{60} \mathrm{SiO}_{2}^{-} \text {, } \\
{ }^{76} \mathrm{SiO}_{3}^{-},{ }^{7} 9 \mathrm{PO}_{3}^{-} \text {(Silva et al., 2000) }\end{array}$ \\
\hline Dust/bio & Same as dust but also with biological markers ${ }^{26} \mathrm{CN}^{-},{ }^{42} \mathrm{CNO}^{-}$ \\
\hline Aged marine (aged SS) & $\begin{array}{l}\text { Same as fresh marine but also with }{ }^{108} \mathrm{Na}_{2} \mathrm{NO}_{3}^{+},{ }^{46} \mathrm{NO}_{2}^{-},{ }^{62} \mathrm{NO}_{3}^{-},{ }^{147} \mathrm{Na}\left(\mathrm{NO}_{3}\right)_{2}^{-}(\mathrm{Gard} \\
\text { et al., 1998) }\end{array}$ \\
\hline Fresh marine $(\mathrm{SS})$ & $\begin{array}{l}{ }^{23} \mathrm{Na}^{+},{ }^{24} \mathrm{Mg}^{+},{ }^{39} \mathrm{~K}^{+},{ }^{40} \mathrm{Ca}^{+},{ }^{81,83} \mathrm{Na}_{2} \mathrm{Cl}^{+},{ }^{35,37} \mathrm{Cl}^{-},{ }^{58} \mathrm{NaCl}^{-},{ }^{93,95,97} \mathrm{NaCl}_{2}^{-}, \\
\left.151,153,155 \mathrm{Na}_{2} \mathrm{Cl}_{3}^{-} \text {(Gard et al., } 1998\right)\end{array}$ \\
\hline
\end{tabular}

\subsection{Derivation of Ångström absorption exponent from aethalometer observations}

The attenuation recorded by the aethalometer was used to derive the aerosol absorption coefficient $\left(\sigma_{\mathrm{ATN}}\right)$ at the instrument's native 5 min resolution following the method described in Collaud Coen et al. (2010) (see their Eq. 2). This value was not corrected and thus not reported directly, as techniques for correcting aethalometer measurements require a coincident multi-channel measurement of aerosol scattering in order to determine backscattering by the filtered particles, and this additional measurement was not taken during CalWater 2015. It is noted that values of $\sigma_{\text {ATN }}$ generally fall in the range reported by previous studies in continental regions (e.g., Table 1 in Chung et al., 2012). The hourly mean aerosol absorption coefficient in the channels 470, 520, 590, and $660 \mathrm{~nm}$ were used to derive the Ångström absorption exponent (AAE), using the relation $\sigma_{\mathrm{ATN}}(\lambda)=C_{0} \lambda^{-\mathrm{AAE}}$. AAE is calculated by regression to the uncorrected $\sigma_{\mathrm{ATN}}(\lambda)$. Note that Weingartner et al. (2003) estimated that errors in $\sigma_{\text {ATN }}$ are only a very weak function of wavelength in the channels used; thus it is expected that instrument errors do not contribute significantly to the estimate of AAE.

\subsection{Assigning particle type to ATOFMS spectra}

ATOFMS and UF-ATOFMS can provide information on size and chemical composition (via mass spectra) for an individual particle. Generally, positive spectra reveal particle source, while negative spectra provides information on the atmospheric processing a particle has undergone (Guazzotti et al., 2001; Sullivan et al., 2007; Prather et al., 2008). ATOFMS, but not UF-ATOFMS, spectra were filtered for periodic radio frequency interference caused by a sub-optimally operating instrument component. A total of 115416 particles were scattered and hit during PGF events, and 1835387 during the control time periods (see Sect. 3.1 for definition of PGF and control periods).

Single-particle spectra and size data were loaded into Matlab (The MathWorks, Inc.) and analyzed via the software toolkit YAADA (http://www.yaada.org/). Particles were divided into clusters based on their mass spectral features via an adaptive neural network (ART-2a, vigilance factor of 0.8 , learning rate of 0.05 , and 20 iterations with a regroup vigilance factor of 0.85) (Rebotier and Prather, 2007; Song et al., 1999). Greater than $95 \%$ of ART-2a analyzed particles were grouped into 11 types based upon their characteristic mass spectra and size distributions. Similar to previous field studies using ATOFMS (Sullivan et al., 2007; Pratt and Prather, 
2009; Cahill et al., 2012; Qin et al., 2012), particle types were assigned by a human operator based upon similarity to known types from previous field and laboratory studies. Calculated standard error in particle fraction was less than $1 \%$ for all particle types and thus was not included in the discussion. These results are summarized in Table 2.

\subsection{Determining aging mechanisms using ATOFMS}

It is important to describe not only particle sources but also secondary aging impacts as the aging mechanism will change the light absorption cross section of carbonaceous aerosols. For instance, a sulfate coating can increase the light-absorbing properties of soot by a factor of 1.6 (Moffet and Prather, 2009). Internally mixed EC and OC have greater absorption profiles than homogeneously mixed particles of either species (Schnaiter et al., 2005). Additionally, aging can increase particle hygroscopicity through condensation and reaction of gases like $\mathrm{NO}_{x}$ or $\mathrm{SO}_{2}$ (Wang et al., 2010; Mochida et al., 2006; Zuberi et al., 2005; Zhang et al., 2008) or oxidation of carbonaceous species (Zuberi et al., 2005; Kotzick et al., 1997). Increased particle hygroscopicity can increase the $\mathrm{CCN}$ activity of particles and their growth factor, profoundly impacting radiative effects. Finally, accumulation of nitrogen species on particles can lead to increased deposition of nitrate and ammonium and impact oceanic biology (Paerl, 1995, 1997).

The ATOFMS is a powerful tool with which to measure particle aging because of its ability to measure singleparticle composition and directly determine the type and extent of particle aging. For similar particles of the same type, relative peak areas (RPAs) qualitatively reflect the amount of a species on a particle in relation to other species (Bhave et al., 2002; Gross et al., 2000; Prather et al., 2008) and thus can be used to investigate the mechanism of aging (Cahill et al., 2012). During this study, the mixing state of single particles with secondary markers was investigated by identifying and comparing peak areas for ammonium $\left({ }^{18} \mathrm{NH}_{4}^{+}\right)$, amines $\left({ }^{58} \mathrm{C}_{2} \mathrm{H}_{5} \mathrm{NHCH}_{2}^{+},{ }^{59} \mathrm{NC}_{3} \mathrm{H}_{9}^{+}\right.$, $\left.{ }^{86}\left(\mathrm{C}_{2} \mathrm{H}_{5}\right)_{2} \mathrm{NCH}_{2}^{+}\right)$, sulfate $\left({ }^{97} \mathrm{HSO}_{4}^{-},{ }^{195} \mathrm{H}_{2} \mathrm{SO}_{4} \mathrm{HSO}_{4}^{-}\right)$, nitrate $\left({ }^{46} \mathrm{NO}_{2}^{-},{ }^{62} \mathrm{NO}_{3}^{-},{ }^{125} \mathrm{H}\left(\mathrm{NO}_{3}\right)_{2}^{-}\right)$, elemental carbon $\left({ }^{12} \mathrm{C}^{+},{ }^{36} \mathrm{C}^{+},{ }^{60} \mathrm{C}^{+}\right)$, and organic carbon $\left({ }^{27} \mathrm{CHN} / \mathrm{C}_{2} \mathrm{H}_{3}^{+}\right.$, ${ }^{29} \mathrm{C}_{2} \mathrm{H}_{5}^{+},{ }^{37} \mathrm{C}_{3} \mathrm{H}^{+},{ }^{43} \mathrm{C}_{2} \mathrm{H}_{3} \mathrm{O}^{+} / \mathrm{CHNO}^{+}$). Other markers of heterogeneous processing were investigated, but no notable patterns emerged. For this analysis, a particle was considered to be an internal mixed with a species if it had an RPA greater than $0.5 \%$ for the characteristic ion markers, similar to the methodology employed by Cahill et al. (2012).

\subsection{Estimates of cloud droplet number concentration and marine stratocumulus albedo change}

Size distribution, hygroscopicity, and CCN concentration measurements were collated from periods classified as PGF and CTL. Cumulative CCN supersaturation spectra, defined as median $\mathrm{CCN}$ concentration as a function of supersaturation were constructed from the integrated $\mathrm{CCN}$ and size distribution data. The spectra were fit to a two-mode hypergeometric model (Cohard et al., 1998) to estimate cloud droplet number concentration (CDNC) for a range of updraft velocity.

The albedo change $\left(\Delta A_{\mathrm{C}}\right)$ of nearshore marine stratocumulus during PGF episodes was determined using Eq. (7) in Platnick and Twomey (1994):

$$
\Delta A_{\mathrm{C}}=\left[A_{\mathrm{C}}\left(1-A_{\mathrm{C}}\right)\left(\chi^{\frac{1}{3}}-1\right)\right]\left[A_{\mathrm{C}}\left(\chi^{\frac{1}{3}}-1\right)+1\right]^{-1},
$$

where $\chi=N_{\mathrm{PGF}} / N_{\mathrm{CTL}}$ is the ratio of CDNC in PGF conditions to CDNC in CTL periods. This analytical formulation relies upon the assumptions of conservative scattering, nearly invariant asymmetry parameter, and constant liquid water path. Furthermore, the estimate we present herein of albedo change during PGF episodes assumes that marine stratocumulus clouds are present near Bodega Bay during PGF and that they are not overtopped by higher cloud layers. The validity of each assumption will be briefly discussed.

Conservative scattering: this assumption is commonly invoked in studies that estimate cloud albedo susceptibility or change (Twomey, 1991; Platnick and Towmey, 1994; Hill and Dobbie, 2008; Hill et al., 2008, 2009; Chen et al., 2011). Liquid cloud particles are generally conservative (single scattering albedo $\sim 1.0$ ) for small to moderate cloud optical depth $\left(\tau_{\mathrm{c}}<23.0\right)$. As we will demonstrate, marine cumulus and stratocumulus cloud layers are nearly always below this threshold during PGF.

Invariant asymmetry: for visible light, cloud droplet scattering asymmetry varies weakly with particle size (Kokhanovsky, 2004). For liquid drops, the variation is primarily approximately $5 \%$ over the range of effective radius from 6 to $19 \mu \mathrm{m}$. We will demonstrate that the estimated change in liquid drop effective radius during and near PGF periods lies well within this range.

Constant liquid water path: this is the least likely of the above-listed assumptions to be valid. Cloud albedo is susceptible to changes in both cloud droplet number concentration and cloud liquid water path. The latter can also vary with cloud droplet number concentration through cloud dynamic pathways including the so-called "evaporation entrainment" and "sedimentation entrainment" effects ( $\mathrm{Lu}$ et al., 2005; Wood, 2007; Hill et al., 2009; Chen et al., 2011). The impact of these feedbacks to cloud albedo through the dynamics that control cloud liquid water path vary strongly with environmental conditions and in some cases can cancel the direct increase in cloud albedo resulting from an increase in cloud droplet number concentration. Environmental conditions during PGF (greater likelihood of very dry air above the marine boundary layer, and an increase in large-scale subsidence and thus increased low-level static stability) have been found to favor competing effects on susceptibility through the entrainment effects (e.g., Wood, 2007; Chen et al., 2011). 
Table 3. PGF events observed during CalWater 2015 and their significant parameters following N06. Ranks are out of 67 (62 cases from N06 plus 5 from CalWater 2015).

\begin{tabular}{lrrrrrrr}
\hline $\begin{array}{l}\text { Start date } \\
\text { (MM/DD/YYYY), } \\
\text { time (UTC) }\end{array}$ & $\begin{array}{r}\text { Duration } \\
\text { (h) (rank) }\end{array}$ & $\begin{array}{r}\text { Jet altitude } \\
(\mathrm{m} \text { m.s.l.) } \\
\text { (rank) }\end{array}$ & $\begin{array}{r}\text { Jet maxima } \\
\left(\mathrm{m} \mathrm{s}^{-1}\right) \\
(\text { rank })\end{array}$ & $\begin{array}{r}\text { Jet dir. } \\
\left({ }^{\circ}\right)\end{array}$ & $\begin{array}{r}\text { Gap folding } \\
\text { height }(\mathrm{m} \mathrm{m.s.l.)} \\
(\text { rank })\end{array}$ & $\begin{array}{r}\text { Vertical shear } \\
\text { across folding alt } \\
\left(\mathrm{m} \mathrm{s}^{-1}\right)(\text { rank })\end{array}$ & $\begin{array}{r}\text { Precipitation at } \\
\text { BBY (mm) } \\
(\text { rank })\end{array}$ \\
\hline $01 / 14 / 2015,13: 00$ & $31(5)$ & $307(47)$ & $10.0(16)$ & 96 & $622(20)$ & $12.8(46)$ & $0(67)$ \\
$01 / 25 / 2015,11: 00$ & $8(44)$ & $1146(1)$ & $15.7(2)$ & 79 & $1776(1)$ & $3.7(67)$ & $0(67)$ \\
$01 / 26 / 2015,12: 00$ & $10(33)$ & $202(47)$ & $8.6(37)$ & 98 & $517(28)$ & $12.4(48)$ & $0(67)$ \\
$02 / 04 / 2015,07: 00$ & $9(38)$ & $202(47)$ & $8.8(33)$ & 122 & $517(28)$ & $7.8(62)$ & $0(67)$ \\
$03 / 05 / 2015,13: 00$ & $8(44)$ & $412(6)$ & $7.6(56)$ & 119 & $727(12)$ & $11.6(50)$ & $0(67)$ \\
\hline
\end{tabular}

The strength of the entrainment feedbacks is strongly dependent on sea surface temperature as well. PGF can occur under a wide range of sea surface temperatures arising from natural variability in the northeastern Pacific Ocean. To disentangle the total susceptibility which may arise from these competing liquid water path feedbacks, a series of large-scale eddy simulations, similar to those in Lu et al. (2005) and Chen et al. (2011), are required. This is beyond the scope of the current study; thus we will only estimate the so-called "Twomey effect" (or cloud albedo first aerosol indirect effect) on albedo which corresponds to the increase in cloud albedo due to an increase in $\mathrm{CCN}$ concentration when liquid water path is held fixed.

The MODIS level 2 cloud products provide swath-level retrievals of liquid cloud optical depth, liquid cloud effective radius, and cloud top pressure twice daily during daylight hours from descending (Terra - 10:15 local time) and ascending (Aqua - 13:45 local time) sun-synchronous orbits. The level 2 cloud products have a nominal spatial resolution of $20 \mathrm{~km}$. For this study, daytime retrievals during PGF conditions from the expanded catalog (N06 PGF events plus Table 3 from this study) during the MODIS operational period (2002-present) were screened to remove pixels over land or more than $75 \mathrm{~km}$ from the coast (offshore extent of PGF air mass found by aircraft and reported in N06) and pixels which likely did not correspond to low-level cumulus or stratocumulus. We followed the cloud type definitions (e.g., Fig. 2 from Rossow and Schiffer, 1999) from the International Satellite Cloud Climatology Project (ISCCP) that rely upon thresholds of both cloud top pressure and cloud optical depth. Pixels for which no cloud information was retrieved were also discarded (no cloud present, or retrieval algorithm failed). The retrieved effective radius was also retained to judge the suitability of the invariant asymmetry assumption. The cloud albedo change reported is thus the estimate of the Twomey effect on albedo during PGF episodes when marine cumulus or stratocumulus are present with clear sky above marine low-level clouds.

\section{Results}

\subsection{Description of PGF cases observed during CalWater 2015}

Table 3 lists all cases which fit the mPGF requirements during CalWater 2015. Hereafter, these will be referred to as PGF(1-5). Some key parameters which describe the PGF layer flow measured by the $449 \mathrm{MHz}$ radar are also summarized in Table 3, along with their ranking among 67 cases (62 cases from N06 plus 5 from CalWater 2015). Note that in all 5 cases both mPGF and elevated $\mathrm{CO}$ are met for a majority of the period; however the listed start time and duration in Table 3 is for mPGF, and in some cases the duration for PGF may be shorter than that listed when the additional elevated $\mathrm{CO}$ constraint is enforced.

\subsection{Air mass properties during PGF}

Figure 3 shows a box-and-whisker plot for the peripheral instrument data. So that all measurements fall on the same scale, each measurement has been normalized according to its all-study mean $\left(\mu_{\text {all }}\right)$ and has been plotted according to its natural logarithm. For $\mathrm{CO}, \mathrm{NO}_{x}$, and $\mathrm{CN}$, the interquartile range during PGF lies entirely above (or nearly so in the case of $\mathrm{CN}$ ) the interquartile range during CTL. The difference in normalized concentration is most dramatic for $\mathrm{NO}_{x}$, for which the minimum hourly concentration during PGF is nearly the median CTL concentration and the maximum CTL concentration is nearly the median PGF concentration. Median APS number concentration integrated from 542 to $19810 \mathrm{~nm}\left(n^{\text {APS }}\right)$ is not preferentially higher during PGF, CTL, or all (ALL) hourly periods, though the range of $n^{\text {APS }}$ for each period varies slightly. $\mathrm{PM}_{2.5}$ is more likely to be elevated during PGF, but its interquartile range overlaps with the interquartile range of $\mathrm{PM}_{2.5}$ during CTL and ALL hourly periods. Mean $\mathrm{PM}_{2.5}$ during ALL hourly periods is estimated to be $14.7 \pm 11.6 \mu \mathrm{g} \mathrm{m}^{-3}$. Mean $\mathrm{PM}_{2.5}$ during CTL periods is estimated to be $14.0 \pm 11.9 \mu \mathrm{g} \mathrm{m}^{-3}$. This estimate increases to $22.9 \pm 16.0 \mu \mathrm{g} \mathrm{m}^{-3}$ during PGF, a mean increase of $64 \%$.

Figure 3 also displays wind rose diagrams for ALL and CTL periods. The distribution of wind directions and speeds 
(a)

(b)

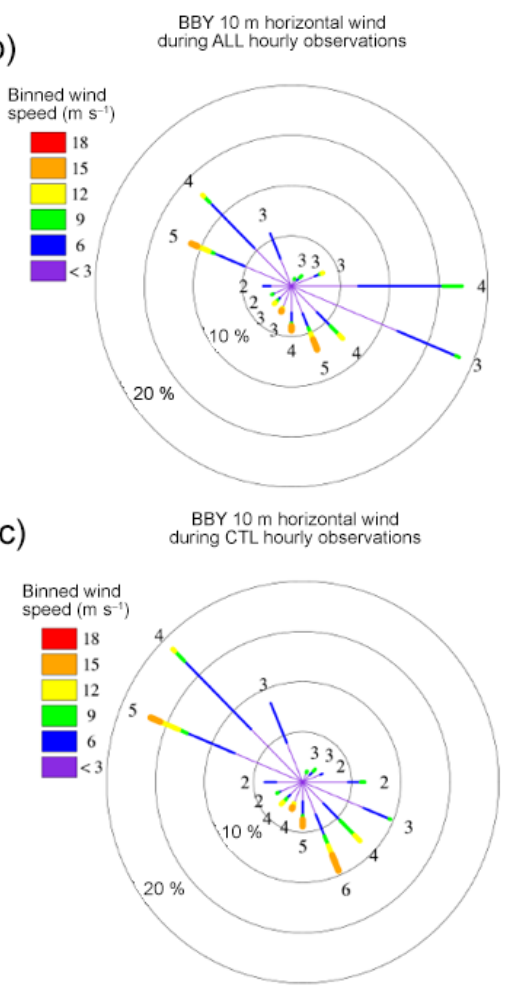

Figure 3. (a) Box-and-whisker plot displaying normalized peripheral measurements during all (ALL - green) hourly CalWater 2015 periods, PGF (PGF - red) periods, and CTL (CTL - blue) periods. (b) BBY $10 \mathrm{~m}$ wind rose diagram for ALL. Rings represent probability of wind from displayed direction; petals represent relative distribution of wind speeds (color bar $-\mathrm{m} \mathrm{s}^{-1}$ ) from the given direction. (c) As in (b) but for CTL periods.

during CTL suggests that these periods are dominated by the land-sea breeze diurnal cycle (BML is situated just east of a shoreline oriented NNW to SSE). The wind rose for PGF is not shown, since wind direction was used in the algorithm for defining PGF.

The range of normalized hourly $\sigma_{\mathrm{ATN}}(\lambda)$ values measured during PGF, CTL, and LOCAL periods is shown in Fig. 4. The normalization method follows that used in Fig. 3. As discussed in the Methods section, absolute values are uncorrected and thus not reported. The median and upper/lower quartile values of $\sigma_{\mathrm{ATN}}$ were compared to published work (Table 1, Chung et al., 2012), and it was found that they are reasonable for the location and concentration/type of aerosols measured. It should be noted that absorption coefficient median and interquartile ranges are highest during PGF, followed by LOCAL and CTL, and that highest maximum values of $\sigma_{\mathrm{ATN}}$ are observed during LOCAL. The AAE derived from the visible light channels for each period is reported in the figure annotation. The $\operatorname{AAE}(0.98 \pm 0.21)$ during PGF is very close to 1.0 , which is widely accepted to be indicative of fresh soot (Chung et al., 2012). Figure 4 shows that AAE during CTL $(0.87 \pm 0.10)$ decreases when compared to PGF. AAE is expected to decrease with soot particle age (accumulation of organic and nitrate on the particle surfaces). A possible explanation for the decrease in CTL AAE in comparison to PGF is that during PGF direct lower tropospheric transport through the Petaluma Gap brings CV and SFBA brings more freshly emitted soot particles to the measurement site. During CTL periods, fewer soot particles are present (lower absorption coefficient), and those that are measured by the aethalometer have been further aged. In Sect. 4.4, this conclusion is supported by single-particle mixing state analysis, which shows that organic: elemental carbon ratio decreases during PGF periods compared to CTL. The AAE during LOCAL periods is highest at $1.17 \pm 0.11$. This value is closer to that reported for biomass burning (BB; Clarke et al., 2007; Lewis et al., 2008) than is the AAE during PGF or CTL.

Figure 5 shows the average merged size distributions for PGF and CTL sampling periods. CTL periods were marked by lower particle concentrations in the submicron mode and higher particle concentrations in the coarse mode $\left(D_{\mathrm{p}}>\right.$ $1.0 \mu \mathrm{m})$. CTL periods often experienced westerly flows and would be expected to be dominated by marine aerosol from the Pacific Ocean. The marine boundary layer over the remote ocean is typified by low particle concentrations and a significant supermicron mode (Quinn et al., 2015). Integrated average supermicron counts on the APS during CTL periods 


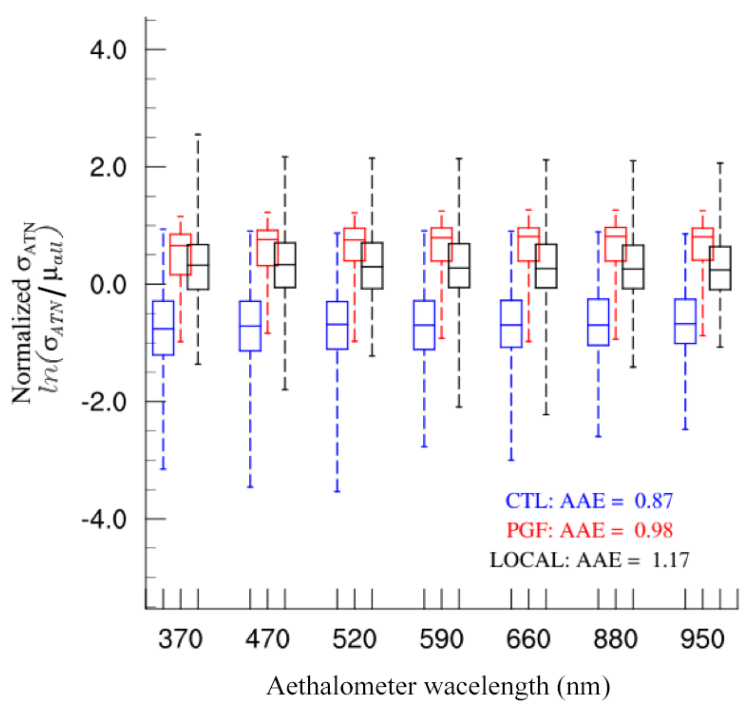

Figure 4. Normalized aethalometer light absorption coefficient at seven wavelengths for hourly periods classified as CTL (blue), PGF (red), and LOCAL (black). Upper/lower box bounds represent upper/lower $25 \%$ values, respectively. Upper/lower whiskers represent $\mathrm{max} / \mathrm{min}$ values, respectively. Box middle represents median value. Also displayed are the AAE values found by regression during each period.

were $14.9 \mathrm{~cm}^{-3}$, compared to $2.4 \mathrm{~cm}^{-3}$ for PGF periods, a decrease of $84 \%$. Fig. $5 \mathrm{~b}$ is a $\log _{10}-\log _{10}$ plot of $D_{\mathrm{p}}$ and shows supermicron particle concentrations approximately an order of magnitude greater. Single-particle composition data from the ATOFMS during these time periods, discussed more in Sect. 4.3, confirmed that the increase in coarse-mode particles could be attributed to greater concentrations of marinetype particles.

PGF events, in contrast, showed a large increase in the number of particles with $D_{\mathrm{p}}<1.0 \mu \mathrm{m}$ and a new ultrafine mode with mode diameter $D_{\mathrm{p}}=36 \mathrm{~nm}$. Figure 5a shows this relationship more clearly, and the corresponding decrease in coarse-mode particles. CN increased by $110 \%$ during PGF compared to CTL, from 311.0 to $650.9 \mathrm{~cm}^{-3}$. These results were also expected, because continental, anthropogenically influenced air masses typically contain smaller and more numerous particles (Tunved et al., 2005). This increase in particle number during PGF events was correlated with the increase in $\mathrm{PM}_{2.5}$ as shown in Fig. 2.

\subsection{Aerosol particle types}

PGF conditions coincide with a shift in particle type away from marine and towards continental. Figure 6 shows pie charts of the sub- and supermicron particle populations for CTL vs. PGF. Percentages indicate the number fraction of particles assigned to the corresponding particle type. The total hit rate for all particles was $20.8 \%$. Panels a and b show the submicron $(0.2-1.0 \mu \mathrm{m})$ particle number fraction by type
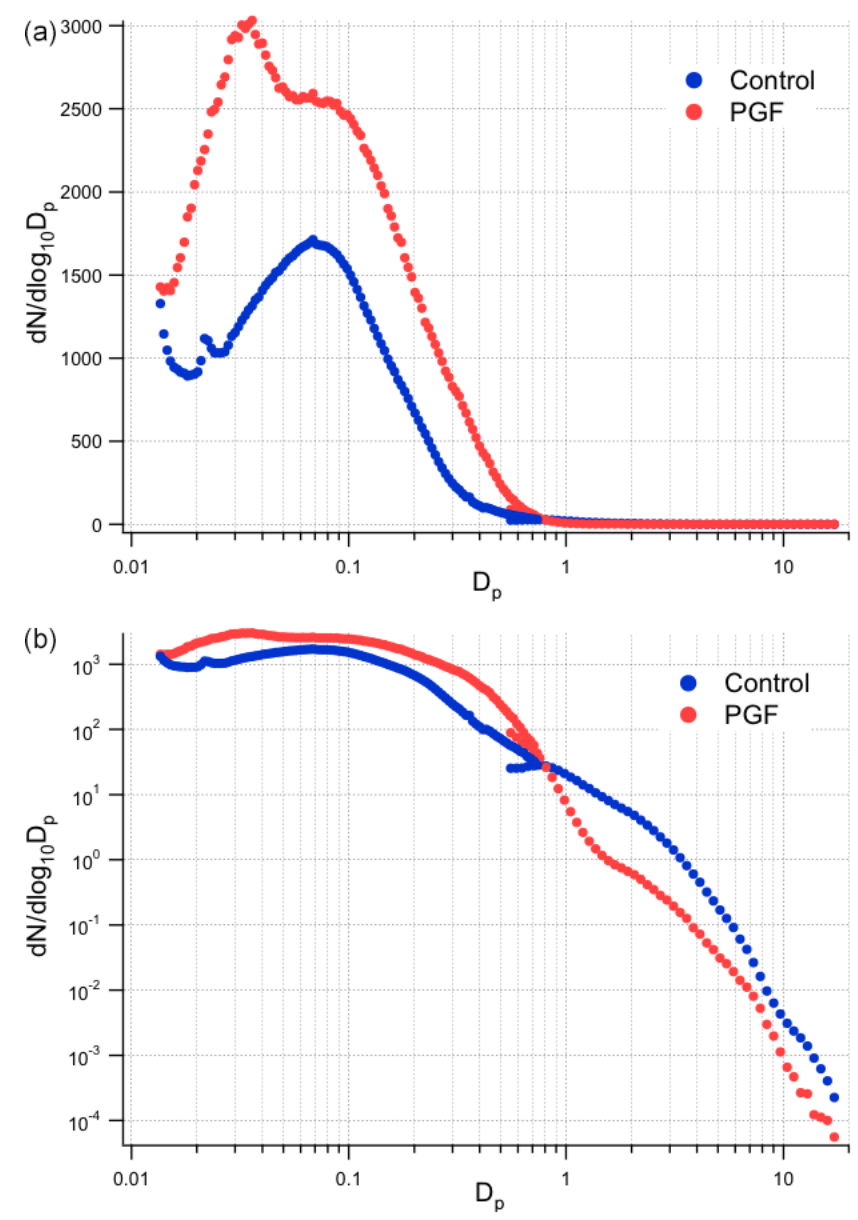

Figure 5. (a) Composite merged SMPS-APS size distribution displayed as for PGF (red) and CTL (blue) periods. (b) As in (a) except displayed on a $\log$ axis.

during CTL (1 222274 particles) and PGF (164952 particles), respectively. PGF had approximately the same level of submicron BB particles. However, there was a large increase in elemental carbon-organic carbon (ECOC) (20-28\%) and ammonium nitrate (AN) (10-28\%) particle types. These two types have both been linked to anthropogenic activity. The ECOC type has been observed before with the aging of fuel emissions (Hughes et al., 2000) in the Los Angeles Basin during stagnant conditions with high pollutant concentrations. Similarly, the California Central Valley is an area of elevated hydrocarbon fuel emissions and frequent long-lived lower tropospheric inversions, and it might be expected to support the formation of ECOC particles. AN particles have been linked to the accumulation of ammonia and nitric acid on particles (Qin et al., 2012) and nucleation by reactions between ammonia and nitric acid (Russell and Cass, 1986; Hughes et al., 2002), gases strongly correlated with anthropogenic activity. Marine aerosols make up a sizable fration of submicron particles during CTL (SS and aged SS). However, these particles are much less prominent during PGF. 
(a)

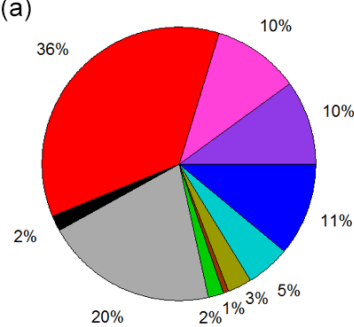

(c)

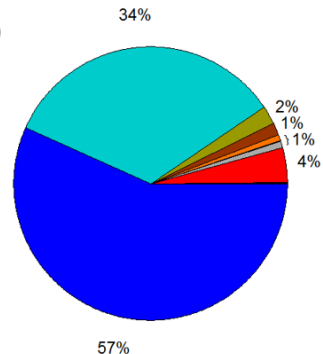

(b)

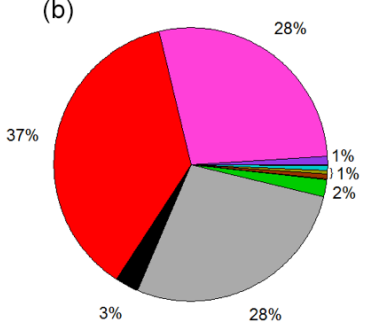

(d)

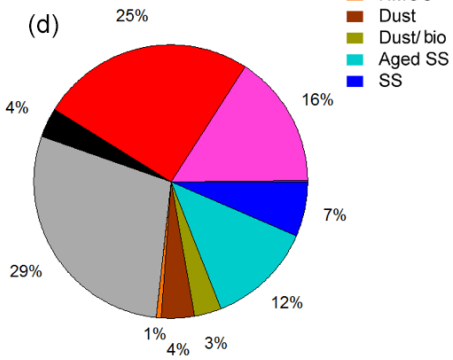

Figure 6. Pie charts for sub- (top panels) and supermicron (bottom panels) particle types for CTL (left panels) and PGF (right panels). Description of particle classifications can be found in Table 2.

The increase in ECOC and AN and decrease in marine particle types reinforce the conclusion that PGF air masses originate continentally and have a strong anthropogenic character.

The clearest delineation in particle type was observed in the supermicron fraction $(1.0-3.0 \mu \mathrm{m})$. Panels $\mathrm{c}$ and $\mathrm{d}$ of Fig. 6 show that over $90 \%$ of CTL supermicron particles (544612 total particles) were either fresh or aged marine particles, while less than $20 \%$ were of marine origin during PGF. During PGF, supermicron particles (25 457 total particles) were primarily comprised of BB; ECOC; AN; and EC, a byproduct of fuel combustion. Additionally, the majority of PGF marine particles showed markers of reacting with nitric acid (Gard et al., 1998). This contrasts CTL marine particles, which were primarily unreacted.

The dust and dust/bio types also increased during PGF. The CV, despite its agricultural production, is a semiarid environment and can be a significant source of dust. Conversely, BML air masses during CTL periods were heavily influenced by the Pacific Ocean and thus were not expected to contain much dust. The shift in supermicron particle composition away from marine particles to anthropogenic and dust particle types supports the conclusion that PGF air masses likely originate from the $\mathrm{CV}$.

\subsection{Aging processes observed through secondary species markers}

Figure 7 shows the sulfate : nitrate ratio (SN) of particles separated by type. Unmodified peak ratios are dependent upon which peak is in the denominator, i.e., whether or not the ratio is greater than 1 , thus potentially skewing the data. To ac-
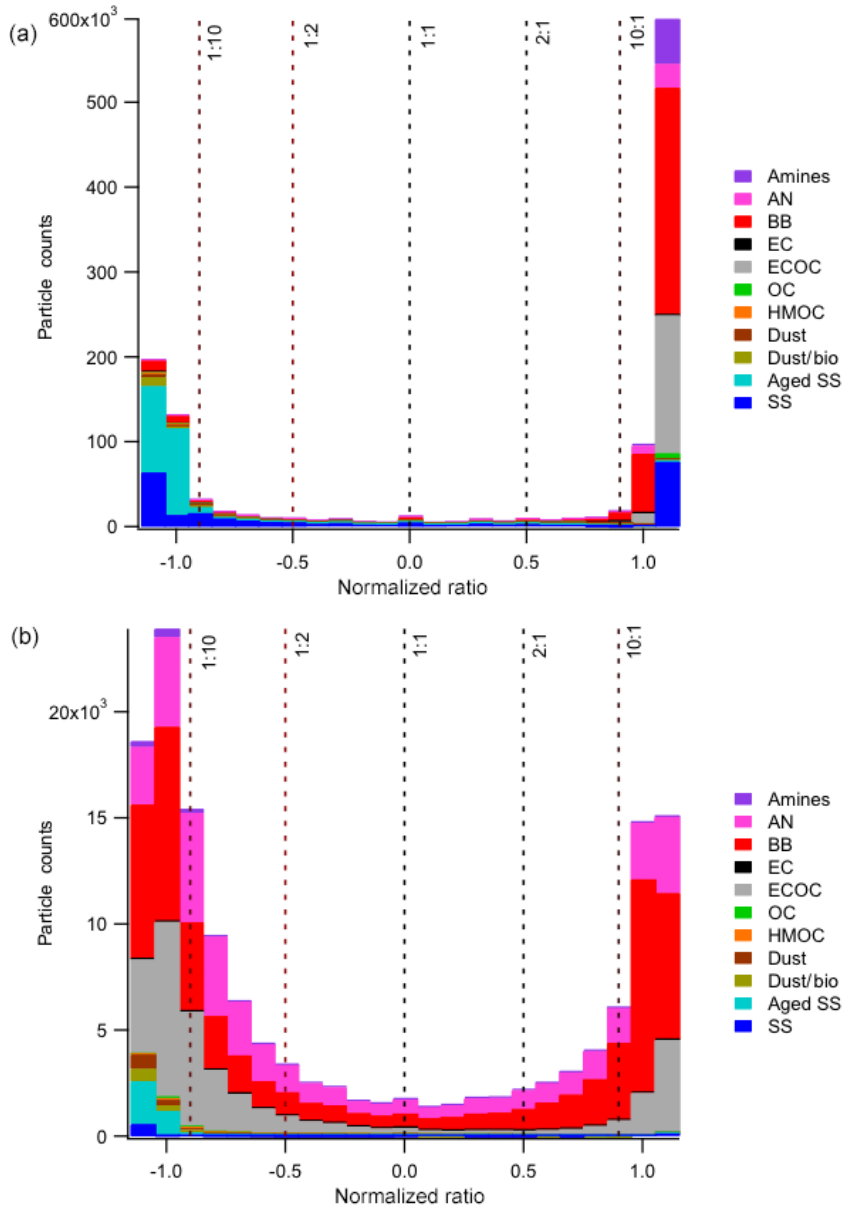

Figure 7. (a) Particle sulfate : nitrate ion ratio distribution for CTL periods. Values $<0$ indicate more nitrate than sulfate, and values $>0$ indicate more sulfate than nitrate. Ratios representing $1: 1,2: 1$, and $10: 1$ are shown by vertical dashed lines. Significant particle types are represented by separate colors. (b) as in (a) but during PGF periods.

count for this, we calculated the normalized peak ratio by the following: ratio $>1$, normalized peak ratio $=1-(1 /$ ratio $)$; ratio $<1$, normalized peak ratio $=$ ratio -1 ; and ratio $=1$, normalized peak ratio $=0$. As ratios approach -1 or 1 , they are exponentially increasing, while close to 1 the RPA of each species is essentially the same. This results in a broader range of ratios for bins near -1 or 1 , while the bins near 0 include a smaller range of ratios. The left panel depicts the SN for CTL particles. The majority of particles showed higher $\mathrm{SN}$ ratios, indicating that aging primarily occurred through the accumulation of sulfate. The exception to this rule was the SS type, which can react with $\mathrm{NO}_{x}$ species in a displacement reaction to liberate $\mathrm{HCl}$ (Gard et al., 1998; Cahill et al., 2012). PGF particles showed a SN ratio biased toward nitrate accumulation, indicating that the primary and most important aging mechanism was through $\mathrm{NO}_{x}$ pathways. 

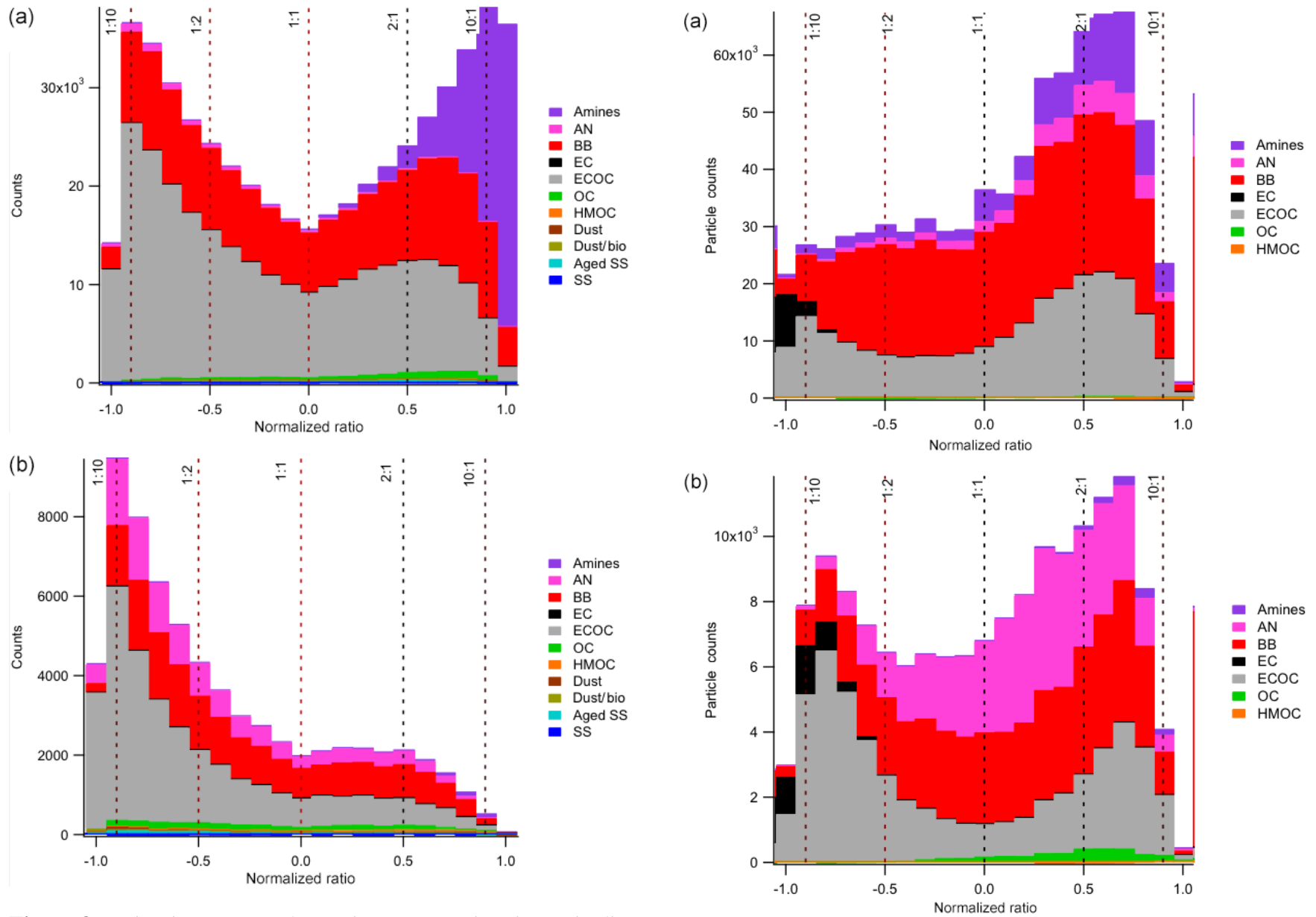

Figure 8. As in Fig. 7 except that amines : ammonium ion ratio distributions are shown.

In addition to probing the partitioning of acidic species, basic species like amines and ammonium were investigated. Figure 8 shows the normalized ratio for amines : ammonium ratio (AA). The AA for CTL particles shows fairly equal partitioning for all particle types. During PGF the average peak area of amine peaks $\left({ }^{58} \mathrm{C}_{2} \mathrm{H}_{5} \mathrm{NHCH}_{2}^{+},{ }^{59} \mathrm{NC}_{3} \mathrm{H}_{9}^{+}\right.$, $\left.{ }^{86}\left(\mathrm{C}_{2} \mathrm{H}_{5}\right)_{2} \mathrm{NCH}_{2}^{+}\right)$in particles actually increased, but the AA ratio shifted toward ammonium because the ammonium content of particles increased much more. The area surrounding BML contains animal husbandry but no industrial-scale farming. The shift in basic species partitioning indicates that PGF particles originate from a large source of ammonium. The CV region contains many more industrial-scale farms where ammonium is employed, and thus this change in aging shows that the PGF air mass likely originates within the CV.

Previous studies (Cahill et al., 2012) have used the ATOFMS to determine the internal mixing state of carbonaceous particles. Figure 9 shows the organic carbon : soot ratio as calculated by the ATOFMS, seperated by particle type. CTL particles appear to have relatively higher amounts of

OC, most notably in the amine particle types and, unsurprisingly, the OC type. Amines consist of organic carbon chains bound to nitrogen atoms, so it is also unsurprising that these particles would have high OC: EC ratios. The ratio plot indicates that PGF particles contain more EC relative to CTL particles. This is despite the appearance of the AN particle type, which had greater OC character. These OC / EC ratio plots agree with the aethalometer-derived AAE, which suggest that the soot was less aged during PGF than during CTL periods.

In summary this analysis shows that the preeminent aging mechanisms associated with PGF are the accumulation of ammonium and nitrate, in accordance with previous studies on Central Valley particle composition (Qin and Prather, 2006). Amine accumulation was also observed in ECOC and AN particles but was determined to not be as significant as ammonium. Accumulation of nitrogen species on aerosol particles is important as it increases the risk of nitrogen deposition into coastal waters, which can lead to ecosystem degradation (Ryther and Dunstan, 1971; Paerl, 1995, 1997). 
The shift toward internal mixtures containing elemental carbon and away from particulate matter containing primarily organic carbonaceous species during PGF suggests that gap flow may cause increased solar absorption by near-surface aerosols, especially in visible wavelengths. This potential impact is corroborated by the aethalometer PGF and CTL measurements.

\subsection{CCN and cloud droplet spectra}

Figure 10 displays the cumulative $\mathrm{CCN}$ supersaturation spectrum (versus liquid supersaturation) transformed from the size-resolved CCN data and the CDNC for updraft velocities between 0.1 and $10 \mathrm{~m} \mathrm{~s}^{-1}$. CCN concentration is enhanced during PGF by 2.8 to 3.0 for a wide range of supersaturations. The increase in $\mathrm{CCN}$ is remarkably consistent across the range due to the confluence of two factors. First, the hygroscopicity parameter - or the contribution of particle chemistry to CCN activation - does not change significantly between PGF and CTL (0.21 vs. 0.20). Second, particle concentrations are larger for all sizes $D<500 \mathrm{~nm}$ during PGF events (Fig. 5). These sizes dominate the spectra in Fig. 10a. As a consequence CDNC increases across all considered cloud updraft speeds during PGF episodes. Figure $10 \mathrm{~b}$ shows that CDNC increases between 125 and $145 \%$, and that this relative increase is expected for all possible cloud types. In the results to follow concerning cloud albedo change during PGF, CDNC increases are considered as a ratio (i.e., $\chi=N_{\mathrm{PGF}} / N_{\mathrm{CTL}}$ ). In this framework, the average ratio, $\chi$, is 2.35 .

\subsection{Impact of PGF on marine cumulus and stratocumulus albedo}

During expanded catalog (see Sect. 3) PGF episodes the observed cloud albedo ranged from 0.01 to 0.63 , with upper (lower) quartile values of $0.43(0.17)$. Using the observed $A_{\mathrm{C}}=0.43(0.17)$ and $\chi \sim 2.35$, Eq. (7) from Platnick and Twomey (1994) estimates that $\Delta A_{C} / A_{C}=0.28(0.16)$. Therefore, clouds that condense on PGF CCN without concomitant changes in liquid water path are expected to be 16 to $28 \%$ more reflective when considering the Twomey aerosol indirect effect. As discussed in the Methods section, the values reported here correspond to PGF episodes where marine cumulus or stratocumulus clouds are present within $75 \mathrm{~km}$ of the shoreline, and, when clear, the marine cloud layer is topped by clear sky.

\section{Summary}

Measurements taken at Bodega Bay, CA, during the CalWater 2015 intensive observing period were used to investigate the impacts of Petaluma Gap flow on local air quality and marine cloud albedo. The kinematics of PGF and its relation to synoptic-scale weather patterns and the Central Valley cold pool have been perviously described in N06. This study is the first attempt to quantify the impact of PGF on the boundary layer air mass and particle chemistry.

Vertically resolved lower tropospheric wind observations and carbon monoxide concentration were used to identify PGF periods during the CalWater 2015 intensive observing period and separate these from CTL periods, during which the BML air mass was influenced neither by PGF nor by heavy pollutant loads from a local source. Five PGF events were identified during Calwater 2015 and were compared to the PGF catalog published in N06 by means of their local weather attributes.

During Calwater 2015 PGF periods, several measures of anthropogenic pollution - including $\mathrm{CO}, \mathrm{NO}_{x}, \mathrm{CN}$, and black carbon mass concentration estimated by a multichannel aethalometer - were consistently elevated when compared to CTL periods. Using SMPS and APS aerosol size spectrometers, we found that aerosol number concentrations increase by $110 \%$ in the submicron size range, while decreasing $84 \%$ in the supermicron size range. Both PGF and CTL periods presented size distributions with a similar accumulation mode near $100 \mathrm{~nm}$. The PGF period composite size distribution contained a prominent mode below $50 \mathrm{~nm}$ which was not present in the CTL composite. This fine mode indicates that particle source and/or degree of particle chemical aging may be significantly different during PGF periods. The particle chemistry of this fine mode could not be investigated because the relevant sizes are below the lower detection limit of the UF-ATOFMS. PGF periods contained $84 \%$ fewer coarse-mode particles than did CTL periods. The relative lack of particles at these sizes is related to a significant change in supermicron particle chemistry found by analyzing single-particle mass spectra. Taken together, the above results demonstrate the change in aerosol physicochemical properties during PGF events.

Single-particle chemical mixing state during PGF events was investigated using UF-ATOFMS and ATOFMS measurements. It was found that submicron particle populations change during PGF to favor ECOC, BB, AN, and EC types at the expense of SS types. The large difference in supermicron particle mixing state is likely related to the shift in prominent wind direction during PGF. The analysis of secondary aging also showed that carbonaceous particles are more likely to contain elemental carbon than organic carbon during PGF episodes. Aethalometer-derived AAE also suggested that observed soot was less aged during PGF periods, but total absorption and total black carbon mass were greater than during CTL. The above results reinforce the hypothesis that PGF could lead to an increase in absorption of solar shortwave radiation by black carbon aerosol, which may be associated with more freshly emitted soot.

PGF and CTL single-particle mass spectra relative peak area ratios were used to investigate particle aging mechanism. PGF particles were much more likely to acquire nitrate than CTL particles, which preferentially contained sulfate. 

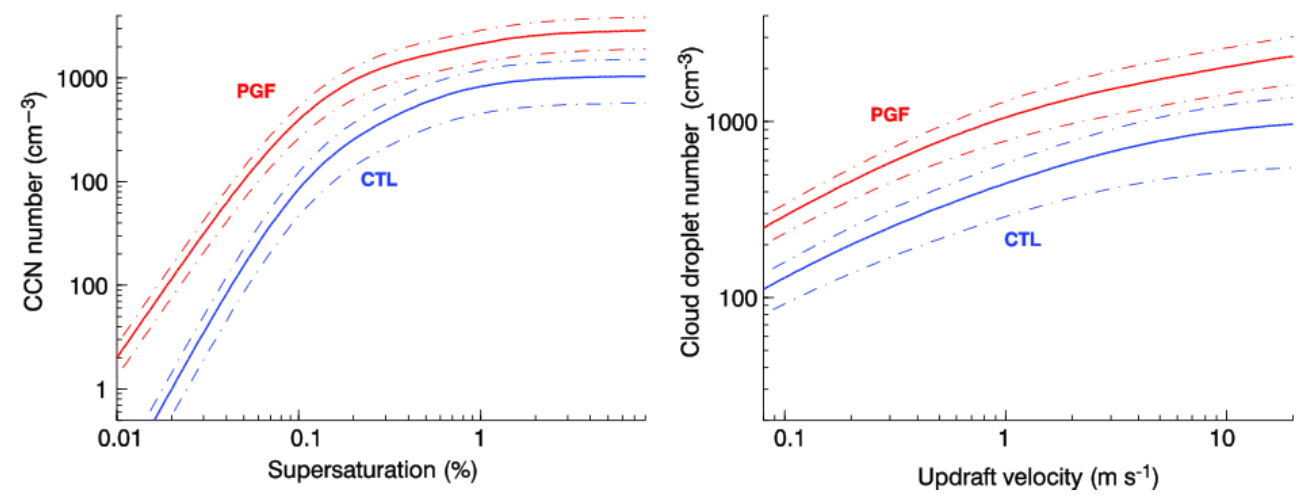

Figure 10. Left: cumulative median CCN supersaturation spectrum PGF periods (blue) and CTL (yellow). Dashed lines approximate the interquartile range. Right: as in left but for predicted cloud droplet number concentration as a function of updraft velocity.

This was especially true for AN, ECOC, BB, and EC particle types during PGF but may not apply to SS and aged SS, which showed a preference for nitrate aging even during CTL periods. The aging of SS by nitrate is a well-documented phenomenon that was also regularly observed during CalWater 2015. Relative peak area analysis also showed that particles are much more likely to chemically age by ammonium than by amines during PGF. This tendency appeared especially strong for $\mathrm{BB}, \mathrm{EC}$, and $\mathrm{ECOC}$ types. While OC type particles increased in relative number during PGF episodes, they appeared to favor the amine aging pathway even during PGF. Together the above results reinforce the hypothesis that PGF could lead to increased deposition of nitrogencontaining particulate matter to the local ecosystem near and offshore of Bodega Bay. This result may also be true in other coastal locations which are periodically influenced by offshore gap flow originating in a $\mathrm{NO}_{x}$ - and ammonia-enriched air mass (e.g., the nearby Salinas Valley, and offshore of the Golden Gate). If increased nitrogen deposition is occurring during PGF episodes, it could lead to eutrophication and algal blooms, as suggested by Paerl $(1995,1997)$.

Particle hygroscopicity, as shown by size-resolved CCN measurements, was nearly invariant between PGF and CTL periods. The model of Cohard et al. (1998) was used to estimate the cloud droplet number concentration resulting from the derived CCN activation curves (Sect. 3.5). The increase found in CDNC was stable across a wide range of updraft velocities. The marine cloud albedo change in response to PGF CCN was estimated using MODIS level 2 cloud products and Eq. (7) from Platnick and Twomey (1994). To first order (assuming constant liquid water path) it is estimated that nearshore marine clouds will brighten by 16 to $28 \%$ (interquartile range) in visible wavelengths during PGF events. This finding supports the hypothesis that PGF conditions may lead to a brightening in nearshore marine stratocumulus clouds through the cloud albedo indirect effect.

The conclusions reached in addressing the three hypotheses posed in this study represent only the first attempt to char- acterize the impact of Petaluma Gap flow on the aerosol direct effect, aerosol indirect effect, and coastal environment in northern central California. Due to the relatively short CalWater 2 intensive observing campaign, these results were drawn from only five PGF events. The data necessary to investigate these hypotheses were drawn from a large multiagency effort including many specialized and operator intensive measurements, which by nature must be short in duration. Longer-term observation, perhaps by less detailed but targeted chemical observations at similar locations, could significantly augment the findings presented here.

During this study, we attempted to detect inter-event differences in relative peak area ratios for secondary aging indicators, but no significant change was observed. In addition, the authors wish to comment that many of the assumptions made (e.g., constant liquid water path) in estimating the impact of PGF on marine cloud albedo change can only be discarded through airborne observations or modeling studies. These were considered beyond the scope of this study but may be valuable future investigations to fully describe the impact of polluted offshore-directed gap flow on marine cloud brightness.

The findings presented herein demonstrate that PGF can impact aerosol number, chemical aging pathways, shortwave absorption, and the number of $\mathrm{CCN}$ available to nearshore marine clouds. These findings are the first of their kind that result from direct observation of an intermittent weather phenomenon that brings anthropogenic pollutants to an otherwise remote region. While the findings follow from in situ observations representative of a small region, we note that the meteorological factors causing Petaluma Gap flow (pooling of cold continental air; an onshore, mountain-normaldirected pressure gradient; a narrow low-elevation gap in the coastal mountain range) certainly exist in other regions. Thus, the introduction of anthropogenically influenced continental air to remote marine environments may modify air quality and aerosol direct and indirect effects in other regions experiencing regular offshore gap flow as well. The authors 
argue that further study of the chemical composition of continental outflow in other regions is necessary to refine current understanding of the impact of human activities on the environment.

\section{Data availability}

The data used in this study is available at doi:10.4246/CW3EMARTIN_20161213_CALWATER2-DATA-

BBYMD5324615234A03D12251238DE7C2CD9EEF.TAR. 
Appendix A: List of abbreviations and acronyms

\begin{tabular}{ll} 
Acronym/abbreviation & Full name \\
\hline AA & Ammonium-to-amine ratio \\
AAE & Aerosol Angström exponent \\
$\Delta A_{\mathrm{C}}$ & Albedo change \\
APS & Aerodynamic particle sizer \\
ATOFMS & Aerosol time-of-flight mass spectrometer \\
BAM & Beta attenuation monitor \\
BC & Black carbon \\
BML & Bodega Marine Laboratory \\
CARB & California Air Resources Board \\
CCN & Cloud condensation nuclei \\
CDNC & Cloud droplet number concentration \\
CN & Condensation nuclei \\
CO & Carbon monoxide \\
CSU & Colorado State University \\
CTL & Control time periods \\
CV & California's Central Valley \\
$D_{\mathrm{m}}$ & Mobility diameter \\
$D_{\mathrm{p}}$ & Particle diameter \\
$D_{\mathrm{va}}$ & Vacuum aerodynamic diameter \\
ESRL & Earth System Research Laboratory \\
mPGF & Meteorological Petaluma Gap flow \\
$n$ APS & Median APS number concentration \\
N06 & Neiman et al. (2006) \\
NOAA & National Oceanic and Atmospheric Administration \\
NPS & National Park Service \\
OC / EC & Organic carbon to elemental carbon ratio \\
PGF & Petaluma Gap flow \\
PM 2.5 & Particulate matter below 2.5 $\mu$ m \\
PSLs & Polystyrene latex spheres \\
RASS & Radio acoustic sounding system \\
RH & Relative humidity \\
RPA & Relative peak area \\
SFBA & North San Francisco Bay Area \\
$\sigma_{\text {ATN }}$ & Aerosol absorption coefficient \\
SMPS & Scanning mobility particle sizer \\
SN & Sulfate to nitrate ratio \\
UCSD & \\
UF-ATOFMS &
\end{tabular}


Acknowledgements. The authors thank all other CalWater and ACAPEX 2015 participants, including those from Pacific Northwest National Laboratories; The National Oceanic and Atmospheric Administration; NASA's Jet Propulsion Laboratory; the Naval Research Laboratory; University of California, Davis; Scripps Institution of Oceanography; Colorado State University; and North Carolina State University. The authors would also like to thank the UC Davis Bodega Marine Laboratory for the use of laboratory and office space, and shipping and physical plant support while collecting data, as well as the California Air Resources Board and the National Park Service for the trailers used for sampling. This research was funded by NSF award number 1451347 (ACM, GCC, KAM, KAP), NSF award number 1450690 (MDP, NR, HT), and NSF award number 1450760 (SAA, SMK, PJD).

Edited by: H. Saathoff

Reviewed by: two anonymous referees

\section{References}

Aschmann, H.: Distribution and peculiarity of Mediterranean ecosystems, in: Mediterranean type ecosystems, Springer, 1119, 1973.

Bhave, P. V., Allen, J. O., Morrical, B. D., Fergenson, D. P., Cass, G. R., and Prather, K. A.: A field-based approach for determining ATOFMS instrument sensitivities to ammonium and nitrate, Environ. Sci. Tech., 36, 4868-4879, 2002.

Cahill, J. F., Suski, K., Seinfeld, J. H., Zaveri, R. A., and Prather, K. The mixing state of carbonaceous aerosol particles in northern and southern California measured during CARES and CalNex 2010, Atmos. Chem. Phys., 12, 10989-11002, doi:10.5194/acp12-10989-2012, 2012.

Chen, Y.-C., Xue, L., Lebo, Z. J., Wang, H., Rasmussen, R. M., and Seinfeld, J. H.: A comprehensive numerical study of aerosolcloud-precipitation interactions in marine stratocumulus, Atmos. Chem. Phys., 11, 9749-9769, doi:10.5194/acp-11-9749-2011, 2011.

Christensen, S. I. and Petters, M.: The role of temperature in cloud droplet activation, J. Phys. Chem. A, 116, 9706-9717, 2012.

Chung, C. E., Kim, S.-W., Lee, M., Yoon, S.-C., and Lee, S.: Carbonaceous aerosol AAE inferred from in-situ aerosol measurements at the Gosan $\mathrm{ABC}$ super site, and the implications for brown carbon aerosol, Atmos. Chem. Phys., 12, 6173-6184, doi:10.5194/acp-12-6173-2012, 2012

Clarke, A., McNaughton, C., Kapustin, V., Shinozuka, Y., Howell, S., Dibb, J., Zhou, J., Anderson, B., Brekhovskikh, V., Turner, H., and Pinkerton, M.: Biomass burning and pollution aerosol over North America: Organic components and their in- fluence on spectral optical properties and humidification response, J. Geophys. Res.-Atmos., 112, D12S18, doi:10.1029/2006JD007777, 2007.

Cohard, J.-M., Pinty, J.-P., and Bedos, C.: Extending Twomey's analytical estimate of nucleated cloud droplet concentrations from CCN spectra, J. Atmos. Sci., 55, 3348-3357, 1998.

Collaud Coen, M., Weingartner, E., Apituley, A., Ceburnis, D., Fierz-Schmidhauser, R., Flentje, H., Henzing, J. S., Jennings, S. G., Moerman, M., Petzold, A., Schmid, O., and Baltensperger, U.: Minimizing light absorption measurement artifacts of the
Aethalometer: evaluation of five correction algorithms, Atmos. Meas. Tech., 3, 457-474, doi:10.5194/amt-3-457-2010, 2010.

Colle, B. A., Loescher, K. A., Young, G. S., and Winstead, N. S.: Climatology of barrier jets along the Alaskan coast, Part II: Large-scale and sounding composites, Mon. Weather Rev., 134, 454-477, 2006.

Eldred, R. A., Cahill, T. A., and Flocchini, R. G.: Composition of $\mathrm{PM}_{2.5}$ and $\mathrm{PM}_{10}$ Aerosols in the IMPROVE Network, J. Air Waste Ma., 47, 194-203, 1997.

Gard, E., Mayer, J. E., Morrical, B. D., Dienes, T., Fergenson, D. P., and Prather, K. A.: Real-time analysis of individual atmospheric aerosol particles: Design and performance of a portable ATOFMS, Anal. Chem., 69, 4083-4091, 1997.

Gard, E. E., Kleeman, M. J., Gross, D. S., Hughes, L. S., Allen, J. O., Morrical, B. D., Fergenson, D. P., Dienes, T., Gälli, M. E., Johnson, R. J., Cass, G. R., Prather, K. A.: Direct observation of heterogeneous chemistry in the atmosphere, Science, 279, 1184 1187, 1998.

Gross, D. S., Gälli, M. E., Silva, P. J., and Prather, K. A.: Relative sensitivity factors for alkali metal and ammonium cations in single-particle aerosol time-of-flight mass spectra, Anal. Chem., 72, 416-422, 2000.

Guazzotti, S. A., Whiteaker, J. R., Suess, D., Coffee, K. R., and Prather, K. A.: Real-time measurements of the chemical composition of size-resolved particles during a Santa Ana wind episode, California USA, Atmos. Environ., 35, 3229-3240, 2001.

Gupta, D., Kim, H., Park, G., Li, X., Eom, H.-J., and Ro, C.-U.: Hygroscopic properties of $\mathrm{NaCl}$ and $\mathrm{NaNO}_{3}$ mixture particles as reacted inorganic sea-salt aerosol surrogates, Atmos. Chem. Phys., 15, 3379-3393, doi:10.5194/acp-15-3379-2015, 2015.

Gyakum, J. R., Anderson, J. R., Grumm, R. H., and Gruner, E. L.: North Pacific cold-season surface cyclone activity: 1975-1983, Mon. Weather Rev., 117, 1141-1155, 1989.

Hill, A. and Dobbie, S.: The impact of aerosols on non-precipitating marine stratocumulus, II: The semi-direct effect, Q. J. Roy. Meteor. Soc., 134, 1155-1165, 2008.

Hill, A., Dobbie, S., and Yin, Y.: The impact of aerosols on nonprecipitating marine stratocumulus. I: Model descrip- tion and prediction of the indirect effect, Q. J. Roy. Meteor. Soc., 134, 1143-1154, 2008.

Hill, A. A., Feingold, G., and Jiang, H.: The influence of entrainment and mixing assumption on aerosol-cloud interactions in marine stratocumulus, J. Atmos. Sci., 66, 1450-1464, 2009.

Hughes, L. S., Allen, J. O., Bhave, P., Kleeman, M. J., Cass, G. R., Liu, D.-Y., Fergenson, D. P., Morrical, B. D., and Prather, K. A.: Evolution of atmospheric particles along trajectories crossing the Los Angeles basin, Environ. Sci. Tech., 34, 3058-3068, 2000.

Hughes, L. S., Allen, J. O., Salmon, L. G., Mayo, P. R., Johnson, R. J., and Cass, G. R.: Evolution of nitrogen species air pollutants along trajectories crossing the Los Angeles area, Environ. Sci. Tech., 36, 3928-3925, 2002.

Kokhanovsky, A.: Optical properties of terrestrial clouds, Earth-Sci. Rev., 64, 189-241, 2004.

Kotzick, R., Panne, U., and Niessner, R.: Changes in condensation properties of ultrafine carbon particles subjected to oxidation by ozone, J. Aero. Sci., 28, 725-735, 1997.

Lentz, S. J. and Chapman, D. C.: Seasonal differences in the current and temperature variability over the northern California shelf 
during the Coastal Ocean Dynamics Experiment, J. Geophys. Res.-Oceans, 94, 12571-12592, 1989.

Leung, L., Prather, K., Ralph, F., Rosenfeld, D., Spackman, J., Fairall, C., DeMott, P., Fan, J., and Zhao, C.: The CalWater 2-ARM Cloud Aerosol Precipitation Experiment (ACAPEX), AGU Fall Meeting Abstracts, 1, 01, 2014.

Lewis, K., Arnott, W. P., Moosmüller, H., and Wold, C. E.: Strong spectral variation of biomass smoke light ab- sorption and single scattering albedo observed with a novel dual-wavelength photoacoustic instrument, J. Geophys. Res.-Atmos., 113, D16203, doi:10.1029/2007JD009699, 2008.

Loescher, K. A., Young, G. S., Colle, B. A., and Winstead, N. S.: Climatology of barrier jets along the Alaskan coast, Part I: Spatial and temporal distributions, Mon. Weather Rev., 134, 437453, 2006

Lu, M.-L. and Seinfeld, J. H.: Study of the aerosol indirect effect by large-eddy simulation of marine stratocumulus, J. Atmos. Sci., 62, 3909-3932, 2005.

Mochida, M., Kuwata, M., Miyakawa, T., Takegawa, N., Kawamura, K., and Kondo, Y.: Relationship between hy- groscopicity and cloud condensation nuclei activity for urban aerosols in Tokyo, J. Geophys. Res.-Atmos., 111, D23204, doi:10.1029/2005JD006980, 2006.

Moffet, R. C. and Prather, K. A.: In-situ measurements of the mixing state and optical properties of soot with im- plications for radiative forcing estimates, P. Natl. Acad. Sci. USA, 106, 1187211877, 2009.

Neiman, P. J., Ralph, F. M., White, A. B., Parrish, D. D., Holloway, J. S., and Bartels, D. L.: A multiwinter analysis of channeled flow through a prominent gap along the northern California coast during CALJET and PACJET, Mon. Weather Rev., 134, 18151841, 2006.

Nguyen, T. K. V., Petters, M. D., Suda, S. R., Guo, H., Weber, R. J., and Carlton, A. G.: Trends in particle-phase liquid water during the Southern Oxidant and Aerosol Study, Atmos. Chem. Phys., 14, 10911-10930, doi:10.5194/acp-14-10911-2014, 2014.

Overland, J. E. and Walter Jr., B. A.: Gap winds in the Strait of Juan de Fuca, Mon. Weather Rev., 109, 2221-2233, 1981.

Paerl, H. W.: Coastal eutrophication in relation to atmospheric nitrogen deposition: current perspectives, Ophelia, 41, 237-259, 1995.

Paerl, H. W.: Coastal eutrophication and harmful algal blooms: Importance of atmospheric deposition and groundwa- ter as "new" nitrogen and other nutrient sources, Limnol. Oceanogr., 42, 1154-1165, 1997.

Petters, M. D. and Kreidenweis, S. M.: A single parameter representation of hygroscopic growth and cloud condensation nucleus activity, Atmos. Chem. Phys., 7, 1961-1971, doi:10.5194/acp-71961-2007, 2007.

Petters, M. D., Carrico, C. M., Kreidenweis, S. M., Prenni, A. J., DeMott, P. J., Collett, J. L., and Moosmüller, H.: Cloud condensation nucleation activity of biomass burning aerosol, J. Geophys. Res.-Atmos., 114, D22205, doi:10.1029/2009JD012353, 2009.

Petters, M. D., Taylor, H. P., Attwood, S., Kreidenweis, S. M., DeMott, P. J., Rothfuss, N. E., Prather, K. A., and Martin, A.: Aerosol characteristics in and around landfalling Atmospheric Rivers and marine air intrusions observed during the Calwater 2015 campaign, J. Atmos. Sci., in preparation, 2017.
Platnick, S. and Twomey, S.: Determining the susceptibility of cloud albedo to changes in droplet concentration with the Advanced Very High Resolution Radiometer, J. App. Meteor., 33, 334-347, 1994.

Platnick, S., King, M. D., Ackerman, S., Menzel, W. P., Baum, B., Riedi, J. C., and Frey, R.: The MODIS cloud products: Algorithms and examples from Terra, IEEE T. Geosci. Remote Sens., 41, 459-473, 2003.

Prather, K. A., Hatch, C. D., and Grassian, V. H.: Analysis of atmospheric aerosols, Annu. Rev. Anal. Chem., 1, 485-514, 2008.

Pratt, K. A. and Prather, K. A.: Real-time, single-particle volatility, size, and chemical composition measurements of aged urban aerosols, Environ. Sci. Tech., 43, 8276-8282, 2009.

Qin, X., Pratt, K. A., Shields, L. G., Toner, S. M., and Prather, K. A.: Seasonal comparisons of single-particle chemical mixing state in Riverside, CA, Atmos. Environ., 59, 587-596, 2012.

Qin, X. and Prather, K. A.: Impact of biomass emissions on particle chemistry during the California Regional Particulate Air Quality Study, Int. J. Mass Spectrom., 258, 142-150, 2006.

Quinn, P. K., Collins, D. B., Grassian, V. H., Prather, K. A., and Bates, T. S.: Chemistry and related properties of freshly emitted sea spray aerosol, Chem. Rev., 115, 4383-4399, 2015.

Ralph, F., Prather, K., Cayan, D., Spackman, J., DeMott, P., Dettinger, M., Fairall, C., Leung, R., Rosenfeld, D., Rutledge, S., Waliser, D., White, A. B., Cordeira, J., Martin, A., Helly, J., and Intrieri, J.: CalWater Field Studies Designed to Quantify the Roles of Atmospheric Rivers and Aerosols in Modulating US West Coast Precipitation in a Changing Climate, B. Am. Meteorol. Soc., 97, 1209-1228, doi:10.1175/BAMS-D-14-00043.1, 2015.

Rebotier, T. P. and Prather, K. A.: Aerosol time-of-flight mass spectrometry data analysis: A benchmark of clustering algorithms, Anal. Chim. Acta, 585, 38-54, 2007.

Regonda, S. K., Rajagopalan, B., Clark, M., and Pitlick, J.: Seasonal cycle shifts in hydroclimatology over the western United States, J. Clim., 18, 372-384, 2005.

Rossow, W. B. and Schiffer, R. A.: Advances in understanding clouds from ISCCP, B. Am. Meteorol. Soc., 80, 2261-2287, 1999.

Russell, A. G. and Cass, G. R.: Verification of a Mathematical Model for Aerosol Nitrate and Nitric Acid Formation and Its Use for Control Measure Evaluation, Atmos. Environ., 20, 20112025, 1986.

Ryther, J. H. and Dunstan, W. M.: Nitrogen, phosphorus, and eutrophication in the coastal marine environment, Science, 171, 1008-1013, 1971.

Schnaiter, M., Linke, C., Möhler, O., Naumann, K.-H., Saathoff, H., Wagner, R., Schurath, U., and Wehner, B.: Absorption amplification of black carbon internally mixed with secondary organic aerosol, J. Geophys. Res-Atmos., 110, D19204, doi:10.1029/2005JD006046, 2005.

Seinfeld, J. H. and Pandis, S. N.: Atmospheric chemistry and physics: from air pollution to climate change, John Wiley \& Sons, 493-536, 2012.

Solomon, S.: Climate Change 2007 - the physical science basis: Working group I contribution to the fourth assessment report of the IPCC, vol. 4, Cambridge University Press, 2007.

Song, X.-H., Hopke, P. K., Fergenson, D. P., and Prather, K. A.: Classification of single particles analyzed by ATOFMS using an 
artificial neural network, ART-2A, Anal. Chem., 71, 860-865, 1999.

Su, Y., Sipin, M. F., Furutani, H., and Prather, K. A.: Development and characterization of an aerosol time-of-flight mass spectrometer with increased detection efficiency, Anal. Chem., 76, 712719, 2004.

Sullivan, R. C., Guazzotti, S. A., Sodeman, D. A., and Prather, K. A.: Direct observations of the atmospheric processing of Asian mineral dust, Atmos. Chem. Phys., 7, 1213-1236, doi:10.5194/acp-7-1213-2007, 2007.

Tunved, P., Nilsson, E., Hansson, H.-C., Ström, J., Kulmala, M., Aalto, P., and Viisanen, Y.: Aerosol characteristics of air masses in northern Europe: Influences of location, transport, sinks, and sources, J. Geophys. Res.-Atmos., 110, D07201, doi:10.1029/2004JD005085, 2005.

Twomey, S.: The influence of pollution on the shortwave albedo of clouds, J. Atmos. Sci., 34, 1149-1152, 1977.

Twomey, S.: Aerosols, clouds and radiation, Atmos. Environ. AGen, 25, 2435-2442, 1991.

Wang, L., Khalizov, A. F., Zheng, J., Xu, W., Ma, Y., Lal, V., and Zhang, R.: Atmospheric nanoparticles formed from heterogeneous reactions of organics, Nat. Geosci., 3, 238-242, 2010.
Weingartner, E., Saathoff, H., Schnaiter, M., Streit, N., Bitnar, B., and Baltensperger, U.: Absorption of light by soot particles: determination of the absorption coefficient by means of aethalometers, J. Aero. Sci., 34, 1445-1463, 2003.

White, A., Anderson, M., Dettinger, M., Ralph, F., Hinojosa, A., Cayan, D., Hartman, R., Reynolds, D., Johnson, L., Schneider, T., Cifelli, R., Toth, Z., Gutman, S. I., King, C. W., Gehrke, F., Johnston, P. E., Walls, C., Mann, D., Gottas, D. J., and Coleman, T. : A twenty-first-century California observing network for monitoring extreme weather events, J. Atmos. Ocean. Tech., 30, 1585-1603, 2013.

Wood, R.: Cancellation of aerosol indirect effects in marine stratocumulus through cloud thinning, J. Atmos. Sci., 64, 26572669, 2007.

Zhang, R., Khalizov, A. F., Pagels, J., Zhang, D., Xue, H., and McMurry, P. H.: Variability in morphology, hygroscop- icity, and optical properties of soot aerosols during atmospheric processing, P. Natl. Acad. Sci. USA, 105, 10291-10296, 2008.

Zuberi, B., Johnson, K. S., Aleks, G. K., Molina, L. T., Molina, M. J., and Laskin, A.: Hydrophilic properties of aged soot, Geophys. Res. Lett., 32, L01807, doi:10.1029/2004GL021496, 2005. 